\title{
Estimating Midday Leaf and Stem Water Potentials of Mature Pecan Trees from Soil Water Content and Climatic Parameters
}

\author{
Sanjit K. Deb ${ }^{\mathbf{1}}$, Manoj K. Shukla, and John G. Mexal \\ Department of Plant and Environmental Sciences, New Mexico State \\ University, MSC 3Q, P.O. Box 30003, Las Cruces, NM 88003
}

Additional index words. Carya illinoinensis, plant water status, stem water potential, leaf water potential, soil texture, vapor pressure deficit

\begin{abstract}
Diurnal and temporal patterns of stem water potential $\left(\psi_{\text {stem }}\right)$ and leaf water potential $\left(\psi_{\text {leaf }}\right)$ were determined during June to Sept. 2010 and 2011 at lower $(2.5 \mathrm{~m}$ tree height), mid- $(4.6 \mathrm{~m})$, and upper $(7.6 \mathrm{~m})$ canopy positions for two flood-irrigated, mature pecan [Carya illinoinensis (Wangenh.) K. Koch] orchards near Las Cruces, NM. Diurnal measurements of $\psi_{\text {stem }}$ and $\psi_{\text {leaf }}$ at three canopy heights were correlated under both dry and wet soil conditions. However, although soil water contents at Site 2 (silty clay loam texture) remained higher compared with Site 1 (sandy loam), $\psi_{\text {stem }}$ and $\psi_{\text {leaf }}$ values, particularly under dry soil conditions at Site 2, were consistently lower, showing the effect of clayey soil texture on pecan water stress. Diurnal patterns of $\psi_{\text {stem }}$ and $\psi_{\text {leaf }}$ indicated that measurements of $\psi_{\text {stem }}$ and $\psi_{\text {leaf }}$ should be made close to early afternoon (between 1400 and 1500 HR Mountain Standard Time) to evaluate mature pecan water stress, which also corresponded to maximum climatic stress conditions. Midday $\psi_{\text {stem }}$ and $\psi_{\text {leaf }}$ measured at three canopy heights over several irrigation cycles during the 2010 season were correlated with one another, midday soil water content at different depths, and atmospheric vapor pressure deficit (VPD). Multiple regression analysis [between midday $\psi_{\text {stem }}$ or $\psi_{\text {leaf }}$ and midday $\theta_{\text {avg }}$ (soil water content at 0 to $40 \mathrm{~cm}$ ), air temperature $\left(T_{m d}\right)$, and relative humidity $\left.\left(\mathrm{RH}_{\mathrm{md}}\right)\right]$ during the 2010 season revealed that two-parameter regression models $\left[\psi_{\text {stem }}\right.$ or $\psi_{\text {leaf }}=f\left(\right.$ midday $\theta_{\text {avg }}$ and $\left.T_{m d}\right)$ ] were the most significant for the interpretation of midday $\psi_{\text {stem }}$ or $\psi_{\text {leaf }}$ at both sites. Using the two-parameter model, predictions of $\psi_{\text {stem }}$ and $\psi_{\text {leaf }}$ measured on the both shaded and sunlit sides of trees at three canopy heights for 2011 showed good agreement between measured and predicted $\psi_{\text {stem }}$ and $\psi_{\text {leaf }}\left(R^{2}\right.$ ranged from 0.70 to 0.98 ). Two-parameter models derived in an earlier study generally underpredicted $\psi_{\text {stem }}$ both in 2010 and 2011, which further supported the importance of the time of midday $\psi_{\text {stem }}$ and $\psi_{\text {leaf }}$ measurements suggested in this study.
\end{abstract}

Irrigation application in orchards should be timed so that tree water status is maintained at a level sufficient for optimum production. Irrigation scheduling decisions based on plant responses rather than measurements of soil

Received for publication 23 Mar. 2012. Accepted for publication 2 May 2012.

We thank New Mexico State University Agricultural Experiment Station for support and the Specialty Crop Research Initiative (SCRI), USDA-CSREES, for funding this research; $\mathrm{Mr}$ Mid Ray Clark for allowing us to conduct an experiment in his pecan orchard (Site 1); Dr. Rolston St. Hilaire, Department of Plant and Environmental Sciences, New Mexico State University, for providing weather data; Mr. Jeff Hamel, PMS Instrument Company, Albany, OR, for providing the pressure chamber instrument fitted with digital gauge; and Dr. Robert Flynn, Department of Plant and Environmental Sciences, New Mexico State University, and Dr. Masaru Mizoguchi, Department of Global Agricultural Science, the University of Tokyo, Tokyo, Japan, for their helpful suggestions on an earlier draft of the manuscript.

${ }^{1}$ To whom reprint requests should be addressed; e-mailsanjit@nmsu.edu. water status have gained wide acceptance because many features of the plant's physiology respond directly to changes in water status in the plant tissues rather than to changes in the bulk soil water content (or potential) (Jones, 2004). Direct physiological methods including $\psi_{\text {leaf }}$ (Jones, 1990; Meyer and Green, 1980; Scholander et al., 1965) and $\psi_{\text {stem }}$ (Garnier and Berger, 1985; McCutchan and Shackel, 1992) have greater relevance to plant functioning than soil-based measures because these measurements integrate both the effects of soil water available to the plant and the climatic conditions with physiological processes (Jones, 2004; Naor et al., 2006; van Zyl, 1987; Williams et al., 1994), which impact crop productivity directly (Grimes and Williams, 1990; Marsal et al., 2008).

Predawn and midday $\psi_{\text {leaf }}$ are common plant water status parameters for irrigation scheduling in orchards (Intrigliolo and Castel, 2006a; Loveys et al., 2008; Williams and Baeza, 2007). However, studies suggest that midday $\psi_{\text {stem }}$ is a significant and reliable indicator of plant water status for scheduling the irrigation of various crops (e.g., Deb et al., 2011a; Goldhamer and Fereres, 2001;
McCutchan and Shackel, 1992; Naor et al., 2001; Olivo et al., 2009; Shackel et al., 1997; Williams and Baeza, 2007). Williams and Araujo (2002) compared predawn $\psi_{\text {leaf }}$, midday $\psi_{\text {leaf }}$, and midday $\psi_{\text {stem }}$ in grapevines and found that all represented equally viable assessments of the water status of grapevines and were all correlated similarly with the amount of water in the soil profile and leaf gas exchange as well as with one another. Remorini and Massai (2003) confirmed the $\psi_{\text {stem }}$ throughout the day (hourly, from predawn to sunset) and predawn $\psi_{\text {leaf }}$ to be better water status indicators than midday $\psi_{\text {leaf }}$ for young peach trees. Williams and Trout (2005) found measurements of predawn $\psi_{\text {leaf }}$ could not distinguish among higher irrigation regimes, whereas midday $\psi_{\text {stem }}$ measurements provided discrimination because of a closer relationship to soil water potential and transpiration. In contrast, Intrigliolo and Castel (2006a) reported that midday $\psi_{\text {stem }}$ values could not discriminate between irrigation treatments, which were shown to differ based on predawn $\psi_{\text {leaf }}$. However, in another study, Intrigliolo and Castel (2006b) recommended both predawn $\psi_{\text {leaf }}$ and midday $\psi_{\text {stem }}$ as water stress indicators in plum. Conversely, the $\psi_{\text {leaf }}$ has been shown unreliable as an estimate of plant water status in many studies as a result of lack of its correlation with physiological parameters, measures of growth, and amounts of applied water (e.g., Choné et al., 2001; Garnier and Berger, 1985; Naor, 1998).

Little is reported about the midday $\psi_{\text {stem }}$ and midday $\psi_{\text {leaf }}$ for irrigated pecans [Carya illinoinensis (Wangenh.) K. Koch] of southern New Mexico grown under different soil textures (Deb et al., 2011a). Water availability is frequently the most limiting factor for pecan productivity in the lower Rio Grande Valley of southern New Mexico. The shortage of water for irrigation is leading to an emphasis on improving methods of irrigation scheduling. Plant water stress indicators, $\psi_{\text {stem }}$ and $\psi_{\text {leaf }}$, are tools that can help pecan growers to determine the timing of peak water demand by pecans and to make decisions for efficient use of irrigation water. In addition to the lack of general agreement on the most suitable plant water stress indicator, none of the plant-based $\psi_{\text {leaf }}$ and $\psi_{\text {stem }}$ measurements are well adapted for automation of irrigation scheduling or control (Jones, 2004). It is also difficult to sample multiple trees regularly, especially in a commercial pecan orchard. Although it may be possible to use automated stem or leaf psychrometers (Dixon and Tyree, 1984), these instruments are unreliable (Jones, 2004). Consequently, because the pecan response to soil water content varies as a function of evaporative demand, interpretation of $\psi_{\text {stem }}$ and $\psi_{\text {leaf }}$ data in pecans and their subsequent use in irrigation scheduling requires empirical relationships that take into account plant water status, variations in root-zone soil water content, distribution of plant roots, plant growth characteristics in addition to atmospheric conditions, specifically atmospheric evaporative demand.

In a previous study, Deb et al. (2011a) derived empirical relationships among direct 
physiological measurement of pecan water status (midday $\psi_{\text {stem }}$ ), soil water content at shallow depth (0 to $40 \mathrm{~cm}$ ), and midday conditions of atmospheric VPD parameters, especially the climatic parameter $\mathrm{T}_{\mathrm{md}}$. Deb et al. (2011a) also assessed these empirical relationships based on temporal and spatial variations in soil water depletion and root length densities. However, it still remains unclear whether both midday $\psi_{\text {stem }}$ and $\psi_{\text {leaf }}$ can be used equally well to take account of the effects of soil water status and climatic factors. In particular, there is a need to evaluate to what extent these relationships can be used to interpret both midday $\psi_{\text {stem }}$ and midday $\psi_{\text {leaf }}$ in flood-irrigated, mature pecan orchards under contrasting soil types. Furthermore, there is a paucity of quantitative observations on variations in both midday $\psi_{\text {stem }}$ and midday $\psi_{\text {leaf }}$ at different tree heights or different leaf layers of the tree canopy, particularly on both shaded and sunlit sides of the pecan canopy. To our knowledge, literature provides no quantitative data on the diurnal patterns of $\psi_{\text {stem }}$ and $\psi_{\text {leaf }}$ in irrigated mature pecans under different soil textures, when root-zone soil water content and atmospheric conditions are evaluated simultaneously. There is still a question regarding the suitable time for both $\psi_{\text {stem }}$ and $\psi_{\text {leaf }}$ measurements to evaluate pecan water stress under different soil water conditions. Quantifying the effect of climatic conditions on diurnal $\psi_{\text {stem }}$ and $\psi_{\text {leaf }}$ changes at different tree heights in irrigated mature pecan orchards under different soil textures is lacking. Therefore, the objectives of this study were to: 1) evaluate diurnal and temporal patterns of both $\psi_{\text {stem }}$ and $\psi_{\text {leaf }}$ under different soil water status and climatic conditions in flood-irrigated, mature pecan orchards with contrasting soil textures; and 2) evaluate the validity of empirical relationships between both midday $\psi_{\text {stem }}$ and midday $\psi_{\text {leaf }}$ as dependent variables and soil water content and midday climatic parameters as independent variables in these pecan orchards.

\section{Materials and Methods}

Experimental site. Measurements of $\psi_{\text {stem }}$ and $\psi_{\text {leaf }}$ in 25- to 30-year-old 'Western Schley' pecan trees were carried out during June to Sept. 2010 and 2011 growing seasons at two orchards near Las Cruces, NM. A detailed description of these orchards can be found in Deb et al. (2011a, 2011b). Site 1 ( 0.9 ha) consisted of five rows of pecan trees in a diamond pattern with 15 trees in each row, $8 \mathrm{~m}$ between-row spacing, and $15 \mathrm{~m}$ in-row spacing. Site 2 (1 ha), located at New Mexico State University Leyendecker Plant Science Research Center (LPSRC), comprised seven rows of pecan trees in a rectangular pattern $(7 \mathrm{~m} \times 8 \mathrm{~m})$ with 29 trees in each row. Rootzone soil water content and $\psi_{\text {stem }}$ and $\psi_{\text {leaf }}$ were monitored in three representative trees for each site (denoted as east, south, and north tree for Site 1 and north, south, and southwest tree for Site 2, respectively). Both orchards were flood-irrigated with a combination of surface water and groundwater. The climate of the study areas is semiarid, and average annual temperature and precipitation are $17.7^{\circ} \mathrm{C}$ and $297 \mathrm{~mm}$, respectively.

Soil physical properties at Sites 1 and 2 were reported in Deb et al. (2011a, 2011b). Soil texture at Site 1 is sandy loam, and the soil texture is silty clay loam at Site 2 . In accordance with the soil texture, the saturated hydraulic conductivity $\left(\mathrm{K}_{\mathrm{s}}\right)$ for Site 1 was generally higher, and field capacity (FC) and wilting point (WP) water contents at $30 \mathrm{kPa}$ and $1500 \mathrm{kPa}$, respectively, were lower for Site 1 than Site 2. The $\mathrm{K}_{\mathrm{s}}$ for Site 1 ranged from 0.78 to $1.87 \mathrm{~cm} \cdot \mathrm{h}^{-1}$ above $40 \mathrm{~cm}$ soil depth and 3.72 to $3.84 \mathrm{~cm} \cdot \mathrm{h}^{-1}$ below $40 \mathrm{~cm}$. The ranges of $\mathrm{K}_{\mathrm{s}}$ values at Site 2 were between 0.01 and $1.7 \mathrm{~cm} \cdot \mathrm{h}^{-1}$ above $60 \mathrm{~cm}$ and 0.75 and $3.72 \mathrm{~cm} \cdot \mathrm{h}^{-1}$ below $60-\mathrm{cm}$ soil depth. The average $\mathrm{FC}$ and WP water contents were 0.25 and $0.10 \mathrm{~cm}^{3} \cdot \mathrm{cm}^{-3}$ above $40 \mathrm{~cm}$ and 0.15 and $0.05 \mathrm{~cm}^{3} \cdot \mathrm{cm}^{-3}$ below $40 \mathrm{~cm}$ at Site 1 , whereas these parameter values were 0.38 and $0.20 \mathrm{~cm}^{3} \cdot \mathrm{cm}^{-3}$ above $60 \mathrm{~cm}$ and 0.28 and $0.12 \mathrm{~cm}^{3} \cdot \mathrm{cm}^{-3}$ below $60 \mathrm{~cm}$ at Site 2 .

Measurement of stem water potential and leaf water potential. Midday $\psi_{\text {stem }}$ and $\psi_{\text {leaf }}$ (between 1400 and 1500 HR Mountain Standard Time) were determined simultaneously using a pressure chamber (Model 1000 with digital gauge; PMS Instrument Company, Albany, OR) for each of the selected trees at both sites on a weekly basis over several irrigation cycles (i.e., every third and sixth day after irrigation) from June to Sept. 2010 and 2011. In 2010, for determining diurnal patterns, measurements of $\psi_{\text {stem }}$ and $\psi_{\text {leaf }}$ were carried out at each site throughout the day under typical dry and wet soil conditions. At each site, the diurnal $\psi_{\text {stem }}$ and $\psi_{\text {leaf }}$ measurements were made at 1-h intervals from 0800 to $1900 \mathrm{HR}$ and thereafter measurements were made at 2100,0000, 0300, 0600, and $0900 \mathrm{HR}$. For $\psi_{\text {stem }}$ determinations during 2010, on each tree, shoot tips with several leaves on the sunlit sides of the canopy at tree heights of $2.5 \mathrm{~m}, 4.6 \mathrm{~m}$, and $7.6 \mathrm{~m}$ above the soil surface, denoted as lower canopy, midcanopy, and upper canopy, respectively, were enclosed with foil-laminated plastic bags (Deb et al., 2011a). The effect of these bags on leaf temperature was also checked at both sites during a midday $\psi_{\text {stem }}$ and $\psi_{\text {leaf }}$ measurement day (between 1400 and $1500 \mathrm{HR}$ ). Test leaves together with HOBO H8 temperature sensors (Onset Computer Corp., Bourne, MA) were enclosed with bags at lower canopy, midcanopy, and upper canopy positions and temperature inside the bags were recorded at 1-s intervals, which showed no additional leaf heating even on sunlit side leaves (data not presented).

During $\psi_{\text {stem }}$ measurements, the leaves were bagged for $30 \mathrm{~min}$, which effectively stopped the natural transpiration from the leaves, allowing $\psi_{\text {leaf }}$ to equilibrate with the $\psi_{\text {stem }}$ (Fulton et al., 2001). Each shoot tip sealed in foil-laminated plastic bag was excised and then quickly placed into the pressure chamber. The exposed edge of the shoot was carefully observed for the appearance of a drop of water (sap). The rate of pressure increase in the chamber was kept low to avoid errors during each measurement. The time between bagged leaves excision and chamber pressurization was generally less than $30 \mathrm{~s}$. As soon as the water appeared, the corresponding pressure $\left(\psi_{\text {stem }}\right)$ was read from the chamber digital gauge.

On each tree, leaves, chosen for $\psi_{\text {leaf }}$ determinations at lower, mid-, and upper canopy were fully expanded, mature leaves exposed to direct sunlight. For non-bagged leaves, both leaf transpiration effects on water potential values and desiccation of transpiring leaves after excision from the plant have been reported in previous studies (e.g., Fulton et al., 2001; Turner and Long, 1980). Therefore, the targeted leaves were covered with foil-laminated plastic bags and sealed immediately after excision to avoid any further transpiration, and within 5 to $10 \mathrm{~s}$, midday $\psi_{\text {leaf }}$ was determined using the same pressure chamber. During the period of June to Sept. 2011, midday $\psi_{\text {stem }}$ and $\psi_{\text {leaf }}$ at the lower, mid-, and upper canopy were determined simultaneously for each of the selected trees at both sites on both shaded and sunlit side leaves of the tree.

Measurement of soil water content. At each site, time domain reflectometry (TDR) CS616 sensors (Campbell Scientific, Inc., Logan, UT) were installed horizontally at depths of 5, 10, $20,40,60$, and $80 \mathrm{~cm}$ to continuously record volumetric water content $(\theta)$ once every 10 min at under- and outside-canopy locations of selected three trees during the 2010 and 2011 growing seasons. Sensor data were calibrated in situ using gravimetric water content data (Deb et al., 2011a). During the 2009 season, soil cores (11.4 cm in diameter) near the middle of the canopy and just inside the tree dripline were collected up to $100-\mathrm{cm}$ depth for each tree and site to determine rooting depth and root length density (RLD) (Deb et al., 2011a, 2011b). At both sites, according to Deb et al. (2011a, 2011b), total RLD was much higher in the shallow depths $(0$ to $40 \mathrm{~cm})$ than in the deeper depths $(40$ to $80 \mathrm{~cm})$. Deb et al. (2011a) also reported that soil water depletion within the root zone $(0$ to $80 \mathrm{~cm}$ ) was higher in the shallow depths $(0$ to $40 \mathrm{~cm})$. As suggested by Deb et al. (2011a), soil water contents within the shallow depths (i.e., TDR data at depths of $5,10,20$, and $40 \mathrm{~cm}$ ), where RLD was also higher than in the deeper depths, were used to evaluate correlations with the midday $\psi_{\text {stem }}$ and $\psi_{\text {leaf }}$ at each tree and site. At each site, soil water content at shallow depth (0 to $40 \mathrm{~cm})\left(\theta_{\text {avg }}\right)$ was obtained by averaging $\theta$ at soil depths of $5,10,20$, and $40 \mathrm{~cm}$ among selected trees at the time of midday $\psi_{\text {stem }}$ and $\psi_{\text {leaf }}$ measurements.

Estimation of atmospheric vapor pressure deficit. Air temperature, wind speed, relative humidity, and solar radiation at $2 \mathrm{~m}$ height above the ground were continuously recorded by a HOBO U30-NRC weather station (Onset Computer Corporation, Bourne, MA) at Site 1. Rainfall was measured at Site 1 using a tipping bucket measuring at 10-min intervals. Hourly meteorological variables were also obtained from the New Mexico State University 
Fabian Garcia Science Center (FGSC) weather station, $\approx 6 \mathrm{~km}$ southeast of Site 1 , to facilitate weather data comparison with the HOBO weather station. For Site 2, hourly rainfall, air temperature, solar radiation, wind speed, and relative humidity measured at 2-m height were collected from the LPSRC weather station, which is located $\approx 0.1 \mathrm{~km}$ from Site 2. To account for diurnal changes in evaporative demand at both sites, atmospheric VPD values were calculated using Murray's (1967) equations separately for Sites 1 and 2 using the average hourly air temperature and average hourly relative humidity data. For each measurement of midday $\psi_{\text {stem }}$ and midday $\psi_{\text {leaf }}$, midday conditions of VPD at both sites were calculated using $\mathrm{T}_{\mathrm{md}}$ and $\mathrm{RH}_{\mathrm{md}}$ values between $1400 \mathrm{HR}$ and $1500 \mathrm{HR}$. The diurnal and midday VPD were used to evaluate correlations with the diurnal variations of $\psi_{\text {stem }}$ and $\psi_{\text {leaf }}$ and midday $\psi_{\text {stem }}$ and $\psi_{\text {leaf }}$, respectively.

Data analysis. Linear regression analysis was used to explore relationships between dependent and independent variables at both sites, namely, diurnal and midday $\psi_{\text {stem }}$ and $\psi_{\text {leaf }}$ values at lower, mid-, and upper canopy; midday VPD; $\mathrm{T}_{\mathrm{md}} ; \mathrm{RH}_{\mathrm{md}}$; midday $\theta$ at different soil depths; and midday $\theta_{\text {avg }}$. The effect that midday soil water content at shallow depth $\left(\theta_{\text {avg }}\right)$ and midday VPD parameters (climatic parameters $\mathrm{T}_{\mathrm{md}}$, and $\mathrm{RH}_{\mathrm{md}}$ ) had on midday $\psi_{\text {stem }}$ and $\psi_{\text {leaf }}$ was evaluated through multiple regression analysis for the 2010 season. For each tree, one-parameter (dependent variables $\psi_{\text {stem }}$ or $\psi_{\text {leaf }}$ were regressed against independent variables $\theta_{\text {avg }}$ or $\mathrm{T}_{\mathrm{md}}$ ), two-parameter (against independent variables $\theta_{\text {avg }}$ and $\mathrm{T}_{\mathrm{md}}$ or $\mathrm{RH}_{\mathrm{md}}$ and $\mathrm{T}_{\mathrm{md}}$ ), and threeparameter (against independent variables $\theta_{\text {avg, }}$, $\mathrm{T}_{\mathrm{md}}$, and $\mathrm{RH}_{\mathrm{md}}$ ) regression models were derived at both sites. $F$-test was performed to determine whether a regression model with more parameters provided a significant improvement over the regression models with a smaller number of independent parameters (Deb et al., 2011a). The null hypothesis was that a model with higher number of independent parameters did not provide a significantly better fit than models with fewer parameters, and the null hypothesis was rejected if the $F$ calculated from the data was greater than the critical value of the $F$ distribution at 0.05 significant level.

\section{Results and Discussion}

Diurnal pattern of stem water potential and leaf water potential in pecan trees. The diurnal variations of $\psi_{\text {stem }}$ and $\psi_{\text {leaf }}$ of lower canopy, midcanopy, and upper canopy, $\theta$ at soil depths of 10,20 , and $40 \mathrm{~cm}$, and microclimate variables at both Sites 1 and 2 are plotted for dry and wet soil conditions (Figs. 1 and 2). The $\psi_{\text {stem }}$ and $\psi_{\text {leaf }}$ of the both wet and relatively dry soil conditions at both sites decreased rapidly at sunrise (from 0600 $\mathrm{HR}$ ), reached a minimum in early afternoon (between 1400 and $1500 \mathrm{HR}$ ), and rapidly increased in late afternoon (after $1800 \mathrm{HR}$ ).

The differences of both $\psi_{\text {stem }}$ and $\psi_{\text {leaf }}$ values between wet and relatively dry soil
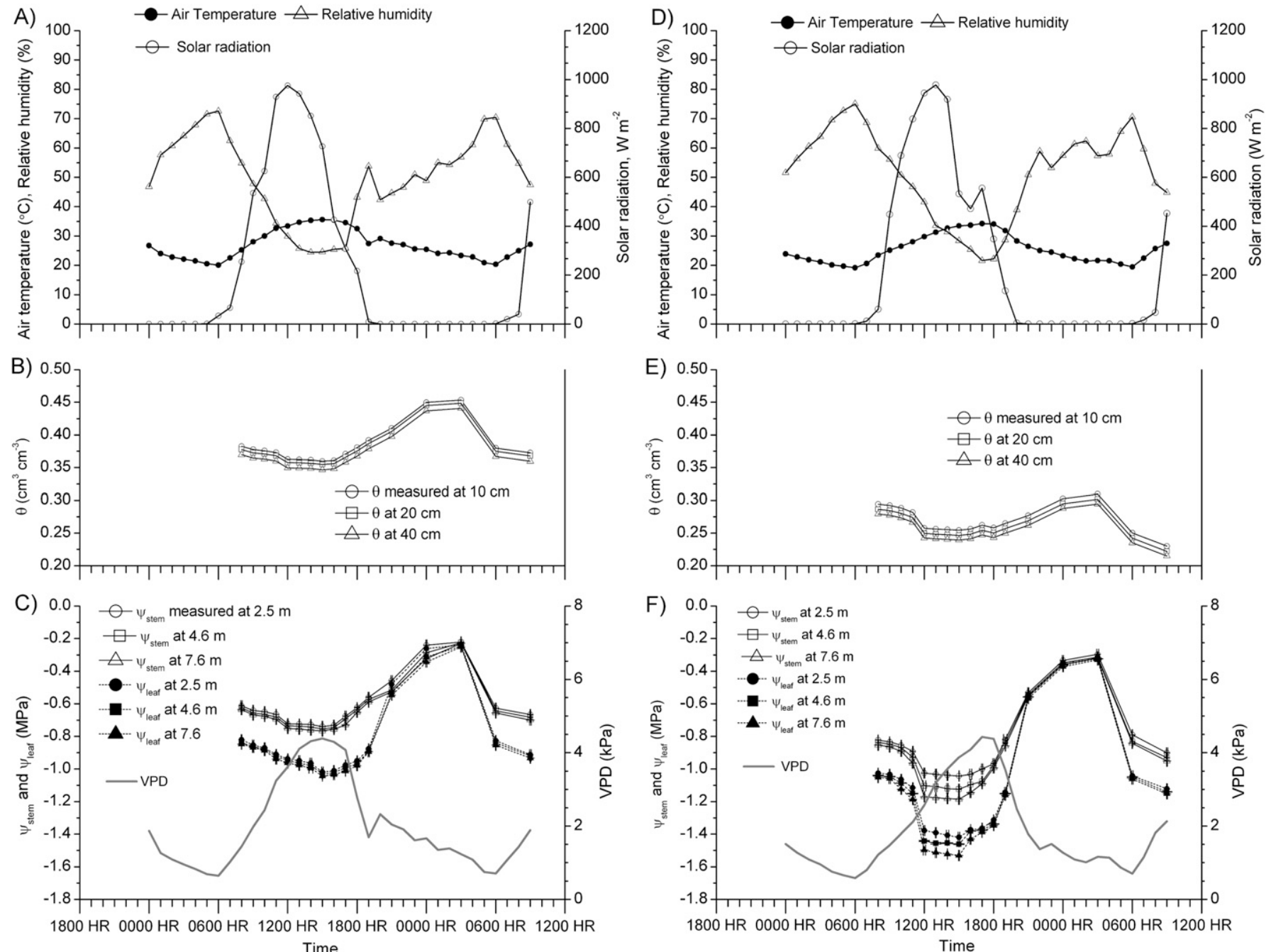

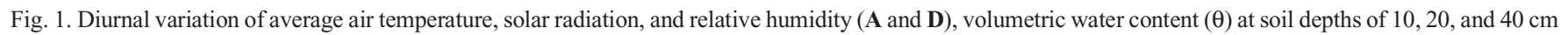
(B and E), and measured stem water potential $\left(\psi_{\text {stem }}\right)$ and leaf water potential $\left(\psi_{\text {leaf }}\right)$ at tree heights of $2.5 \mathrm{~m}($ lower canopy), $4.6 \mathrm{~m}$ (midcanopy), and $7.6 \mathrm{~m}$ (upper canopy) above the soil surface and atmospheric vapor pressure deficit (VPD) (C and F) for pecan trees at Site 1 after an irrigation event on 4 Aug. 2010 : under wet soil conditions during 5 to 6 Aug. 2010 (left; A through C), and under relatively dry soil conditions during 9 to 10 Aug. 2010 (right; D through F). The $\psi_{\text {stem }}$ and $\psi_{\text {leaf }}$ values at each tree height represent the averages of three measurements on the selected east, south, and north pecan trees of Site 1. 

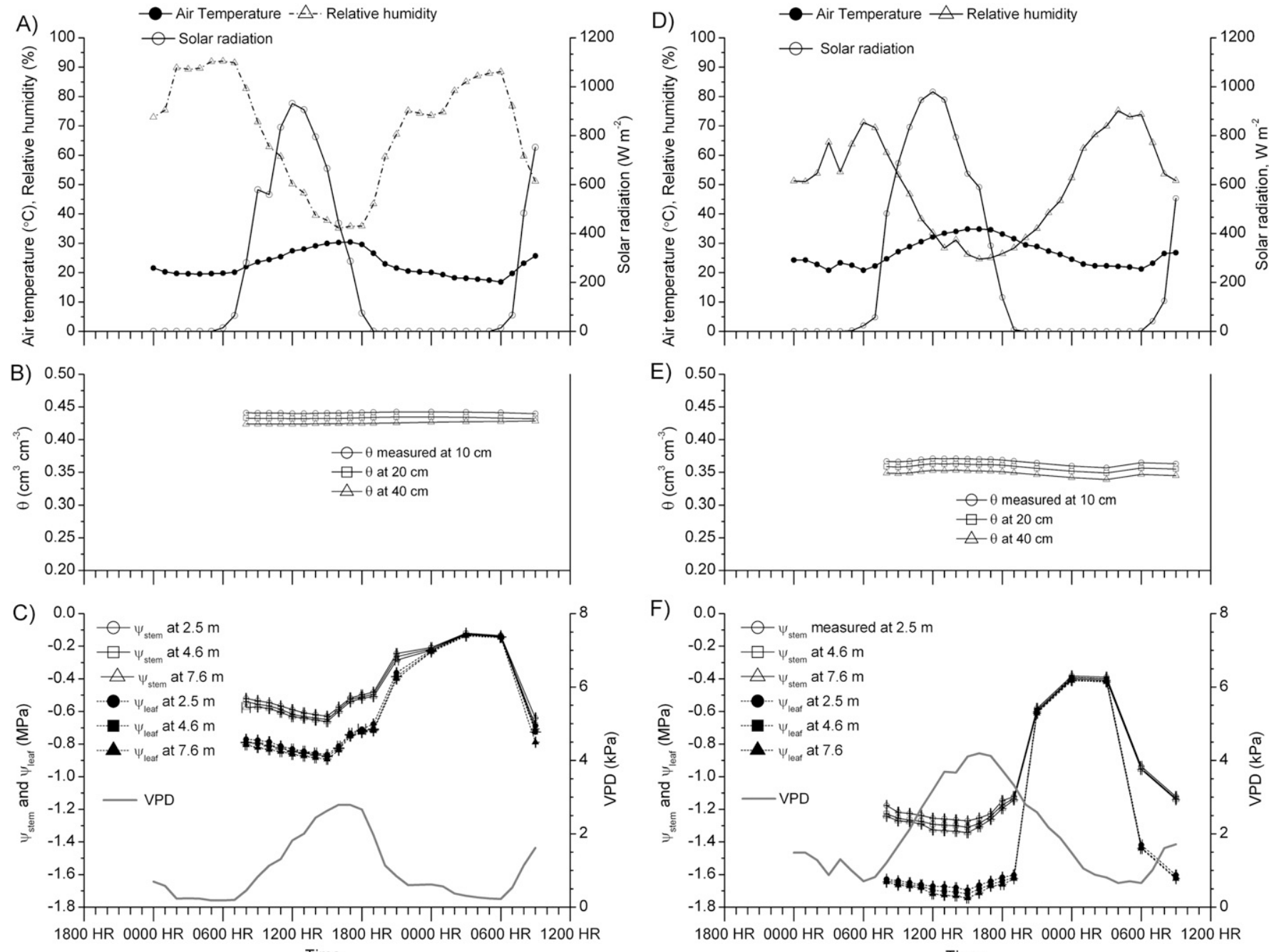

Fig. 2. Diurnal variation of average air temperature, solar radiation, and relative humidity (A and $\mathbf{D})$, volumetric water content $(\theta)$ at soil depths of 10,20 , and $40 \mathrm{~cm}$ (B and $\mathbf{E})$, and measured stem water potential $\left(\psi_{\text {stem }}\right)$ and leaf water potential $\left(\psi_{\text {leaf }}\right)$ at tree heights of $2.5 \mathrm{~m}($ lower canopy), $4.6 \mathrm{~m}$ (midcanopy), and $7.6 \mathrm{~m}$ (upper canopy) above the soil surface and atmospheric vapor pressure deficit (VPD) (C and F) for pecan trees at Site 2: under wet soil conditions during 28 to 29 Aug. 2010 after an irrigation event on 25 Aug. 2010 (left; A through C), and under dry soil conditions during 7 to 8 Aug. 2010 after the previous irrigation applied on 19 July 2010 (right; D through F). The $\psi_{\text {stem }}$ and $\psi_{\text {leaf }}$ values at each tree height represent the averages of three measurements on the selected north, south, and southwest pecan trees of Site 2 .

conditions at both Sites 1 and 2 were straightforward, i.e., under dry soil conditions, $\psi_{\text {stem }}$ and $\psi_{\text {leaf }}$ values were more negative, particularly at early afternoon (between 1400 and $1500 \mathrm{HR}$ ) for both sites. For example, for 5 to 6 Aug. 2010 (Fig. 1C), after an irrigation event on 4 Aug. at Site $1, \psi_{\text {stem }}$ measured at midcanopy ranged from -0.76 (at $1500 \mathrm{HR}$ ) to $-0.23 \mathrm{MPa}$ (at $0300 \mathrm{HR}$ ) under wet soil conditions, whereas $\psi_{\text {leaf }}$ at midcanopy varied from $-1.03(1500 \mathrm{HR})$ to $-0.25 \mathrm{MPa}(0300 \mathrm{HR})$. In contrast, for 9 to 10 Aug. 2010 (Fig. 1F) $5 \mathrm{~d}$ after the irrigation event on 4 Aug. at Site 1, the values of $\psi_{\text {stem }}$ and $\psi_{\text {leaf }}$ at midcanopy under relatively dry conditions ranged from -1.12 (1400 to $1500 \mathrm{HR})$ to $-0.31(0300 \mathrm{HR})$ and -1.46 (1300 to $1500 \mathrm{HR})$ to $-0.32 \mathrm{MPa}$ $(0300 \mathrm{HR})$, respectively. Similar diurnal trends in $\psi_{\text {stem }}$ and $\psi_{\text {leaf }}$ under soil wet and dry conditions (Figs. 2C and Fig. 2F, respectively) were observed at Site 2. However, an important aspect to be noted in Figures $1 \mathrm{~F}$ and $2 \mathrm{~F}$ is that $\psi_{\text {stem }}$ and $\psi_{\text {leaf }}$ values under dry soil conditions exhibited relatively larger amplitude in the silty clay loam Site 2 compared with the sandy loam Site 1 with diurnal variations in $\psi_{\text {stem }}$ and $\psi_{\text {leaf }}$ values at midcanopy ranging from -1.31 to $-0.39 \mathrm{MPa}$ and -1.72 to -0.41 $\mathrm{MPa}$, respectively, under dry soil conditions at Site 2 (Fig. 2F). On the other hand, soil water content at Site 2 remained higher than Site 1 (Figs. 1B, 1E, 2B, and 2E), which could be explained by higher clay content and therefore higher field capacity and water-holding capacity within the root zone at Site 2. Obviously, the relatively lower $\psi_{\text {stem }}$ and $\psi_{\text {leaf }}$ values at Site 2 indicated that soil texture has an important effect on pecan water stress because capillary conductivity of soil influences flow of water from soil to roots. Previous work reported that root-zone soil water depletion at silty clay loam Site 2 was much lower than Site 1 (Deb et al., 2011a), indicating that reduced water adsorption rate by the root system might be related in part to the clayey soil type at Site 2 .

The $\psi_{\text {stem }}$ and $\psi_{\text {leaf }}$ values of both the wet and relatively dry soil conditions at both sites responded to diurnal variations in incoming solar radiation, VPD, air temperature, and relative humidity (Figs. 1 and 2). The rapid decrease in $\psi_{\text {stem }}$ and $\psi_{\text {leaf }}$ values was closely associated with the increase in solar radiation. For example, under the peak solar radiation at $1400 \mathrm{HR}$, the values of $\psi_{\text {stem }}$ and $\psi_{\text {leaf }}$ at Site 1 decreased to -0.74 and -0.98 and to -1.12 and $-1.46 \mathrm{MPa}$ under wet and dry soil conditions, respectively (Fig. 1). At Site 2 , the values of $\psi_{\text {stem }}$ and $\psi_{\text {leaf }}$ during peak solar radiation at $1200 \mathrm{HR}$ decreased to -0.62 and -0.85 and to -1.29 and $-1.70 \mathrm{MPa}$ for wet and dry soil conditions, respectively (Fig. 2). The diurnal trends of $\psi_{\text {stem }}, \psi_{\text {leaf }}$ and VPD under dry and wet soil conditions were also similar at both sites with increases in the evaporative demand (expressed as atmospheric VPD, a function of the air temperature and relative humidity) inducing more negative $\psi_{\text {stem }}$ and $\psi_{\text {leaf }}$ (Figs. 1 and 2). Accordingly, increases in air temperature and decreases in relative humidity during the day induced more negative $\psi_{\text {stem }}$ and $\psi_{\text {leaf }}$ at both 
sites. Because air temperature and relative humidity are easy to determine and usually recorded at weather stations, air temperature or relative humidity might be directly used to interpret diurnal changes of $\psi_{\text {stem }}$ and $\psi_{\text {leaf }}$ in mature pecans under wet and dry soil conditions rather than estimating atmospheric VPD. The diurnal changes of $\psi_{\text {stem }}$ and $\psi_{\text {leaf }}$ and weather data for dry and wet soil conditions at both sites clearly suggest that, to evaluate water stress in mature pecans, measurements of $\psi_{\text {stem }}$ and $\psi_{\text {leaf }}$ should be made close to early afternoon (between 1400 and 1500 HR Mountain Standard Time) when the $\psi_{\text {stem }}$ and $\psi_{\text {leaf }}$ were minimum and responded to prevailing weather conditions that could impact water deficit on a given day. Although site-specific conditions including weather, soil, soil water depletion pattern, management conditions as well as plant properties affect daily dynamics of plant water status, there has been no general consensus regarding the most suitable time to measure midday $\psi_{\text {stem }}$ and $\psi_{\text {leaf }}$, particularly for mature pecan. Time periods of midday $\psi_{\text {stem }}$ measurements have been from 1100 to $1400 \mathrm{HR}$ for grapevines (e.g., Choné et al., 2001), 1200 to 1500 HR for prunes (e.g., McCutchan and Shackel, 1992), and 1300 to $1500 \mathrm{HR}$ for almonds, walnuts, and prunes (e.g., Fulton et al., 2001). Midday $\psi_{\text {stem }}$ and $\psi_{\text {leaf }}$ measurements were also taken only $0.5 \mathrm{~h}$ on either side of solar noon (from 1230 to $1330 \mathrm{HR}$ ) (Williams and Araujo, 2002).

Vertical differences in $\psi_{\text {stem }}$ and $\psi_{\text {leaf }}$ values among different tree heights, i.e., at lower, mid-, and upper canopy, developed soon after sunrise, indicating that a straightforward interpretation of $\psi_{\text {stem }}$ and $\psi_{\text {leaf }}$ determined at a single tree height within the canopy might not be representative. Both $\psi_{\text {stem }}$ and $\psi_{\text {leaf }}$ in the upper canopy were lower during the day at both sites than those in the lower canopy, suggesting that there was relatively more plant water stress at the upper canopy compared with the lower canopy at both sites. Consistently, the lower values of $\psi_{\text {stem }}$ and $\psi_{\text {leaf }}$ associated with tree heights within the canopy were most likely the result of resistances to liquid water flow in the longer pathway to the uppermost leaves (Begg and Turner, 1970; Hellkvist et al., 1974), differences in plant physiology, and flow against gravity. These vertical differences of $\psi_{\text {stem }}$ and $\psi_{\text {leaf }}$ values at lower, mid-, and upper canopy might also be related to the absorption and partitioning of radiation within the canopy, particularly the $\psi_{\text {leaf }}$ might appear to reflect the degree of exposure of the leaves to solar radiation rather than its vertical position in the canopy above the soil surface. The differences in $\psi_{\text {stem }}$ and $\psi_{\text {leaf }}$ between the lower and upper canopy at Site 1 ranged from -0.01 to $-0.2 \mathrm{MPa}$ (Figs. $1 \mathrm{C}$ and $1 \mathrm{~F})$, whereas the differences were between -0.01 and $-0.1 \mathrm{MPa}$ at Site 2 (Figs. $2 \mathrm{C}$ and $2 \mathrm{~F}$ ). At both sites, under both wet and dry soil conditions (Figs. 1 and 2), although leaves were bagged just before excision, the $\psi_{\text {leaf }}$ values were consistently more negative as compared with $\psi_{\text {stem. }}$. This observation is consistent with studies of other crops (e.g., Williams and Araujo, 2002). However, diurnal measurements of $\psi_{\text {stem }}$ and $\psi_{\text {leaf }}$ of both the dry and wet soil conditions at three canopy heights (Figs. 1 and 2) were highly correlated with one another at Site $1\left(R^{2}>0.94, P<0.05\right)$ and Site $2\left(R^{2}>0.95, P<0.05\right)$.

Temporal pattern of midday stem water potential and leaf water potential in pecan trees. The midday $\psi_{\text {stem }}$ at three canopy heights and volumetric water content $(\theta)$ at soil depths of 10,20 , and $40 \mathrm{~cm}$ corresponding to midday $\psi_{\text {stem }}$ measurements during June through Sept. 2010 for all trees at both sites are demonstrated in Figures 3 and 4, respectively. Simultaneous measurements of midday $\psi_{\text {leaf }}$ at three canopy heights for each tree and site made throughout June to Sept. 2010 are not shown. The relationship between midday $\psi_{\text {stem }}$ and midday $\psi_{\text {leaf }}$ determined at midcanopy for selected trees at both sites are shown in Figure 5. As observed in diurnal trends of $\psi_{\text {stem }}$ and $\psi_{\text {leaf }}$ (Figs. 1 and 2), midday $\psi_{\text {leaf }}$ exhibited relatively larger amplitude, i.e., more negative as compared with midday $\psi_{\text {stem }}$, because the midday $\psi_{\text {leaf }}$ values depend partially on water loss from leaves or leaf transpiration rate at the time of measurement (Jones, 2004). Overall, the values of $R^{2}$ between midday $\psi_{\text {stem }}$ and midday $\psi_{\text {leaf }}$ ranged from 0.81 to 0.90 at the lower canopy $(P<0.05), 0.83$ to 0.85 at midcanopy $(P<0.05)$, and 0.84 to 0.85 at the upper canopy $(P<0.05)$ at Site 1 (data not presented). At Site 2, the values of $R^{2}$ between midday $\psi_{\text {stem }}$ and midday $\psi_{\text {leaf }}$ were between 0.86 and 0.90 at the lower canopy $(P<0.05), 0.90$ at midcanopy $(P<0.05)$, and between 0.90 and 0.91 at the upper canopy $(P<0.05)$ (data not presented).

Evaluation of the relationship between midday $\psi_{\text {stem }}$ and midday $\psi_{\text {leaf }}$ has yielded contrasting results in studies for other tree crops. For example, although midday $\psi_{\text {stem }}$ and midday $\psi_{\text {leaf }}$ were highly correlated with one another in grapevines (Stevens et al., 1995; Williams and Araujo, 2002) and peach (Selles and Berger, 1990), Naor et al. (1995) reported a weak correlation between $\psi_{\text {stem }}$ and $\psi_{\text {leaf }}$ for apple trees $\left(R^{2}\right.$ of 0.35$)$. The high correlation of the comparisons between midday $\psi_{\text {stem }}$ and midday $\psi_{\text {leaf }}$ at sandy loam Site 1 and silty clay loam Site 2 indicated that either measurement of midday $\psi_{\text {stem }}$ and $\psi_{\text {leaf }}$ could be a good indicator of the water status of mature pecans regardless of soil type. Moreover, both $\psi_{\text {stem }}$ and $\psi_{\text {leaf }}$ at lower, mid-, and upper canopy did not exhibit significant

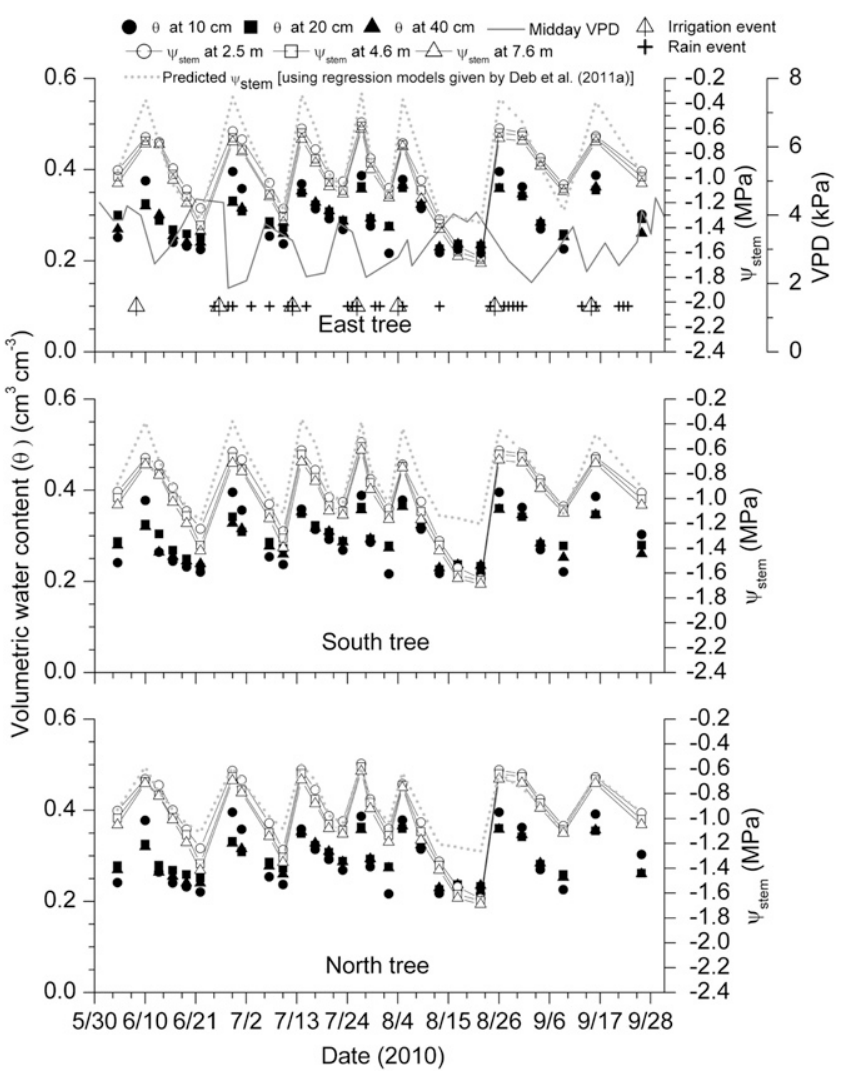

Fig. 3. Midday stem water potential ( $\left.\psi_{\text {stem }}\right)$ at tree heights of $2.5 \mathrm{~m}$ (lower canopy), $4.6 \mathrm{~m}$ (midcanopy), and $7.6 \mathrm{~m}$ (upper canopy) above the soil surface, and volumetric soil water content $(\theta)$ at soil depths of 10 , 20 , and $40 \mathrm{~cm}$ corresponding to $\psi_{\text {stem }}$ measurements taken at identical times during the period from June to Sept. 2010 for the selected east (top), south (middle), and north (bottom) pecan trees of Site 1. The predicted $\psi_{\text {stem }}$ using two-parameter [Deb et al. (2011a); relationships between $\psi_{\text {stem }}$, and measured midday $\theta$ within the 0 - to 40 -cm soil depth $\left(\theta_{\text {avg }}\right)$ and midday air temperature $\left(\mathrm{T}_{\mathrm{md}}\right)$ data during 2010] regression models for each tree are also presented. Estimated midday atmospheric vapor pressure deficit (midday VPD) for Site 1 is depicted in the east pecan's (top) plot. Irrigation and rain events during the period of June to Sept. 2010 are shown in the east pecan's (top) plot. 


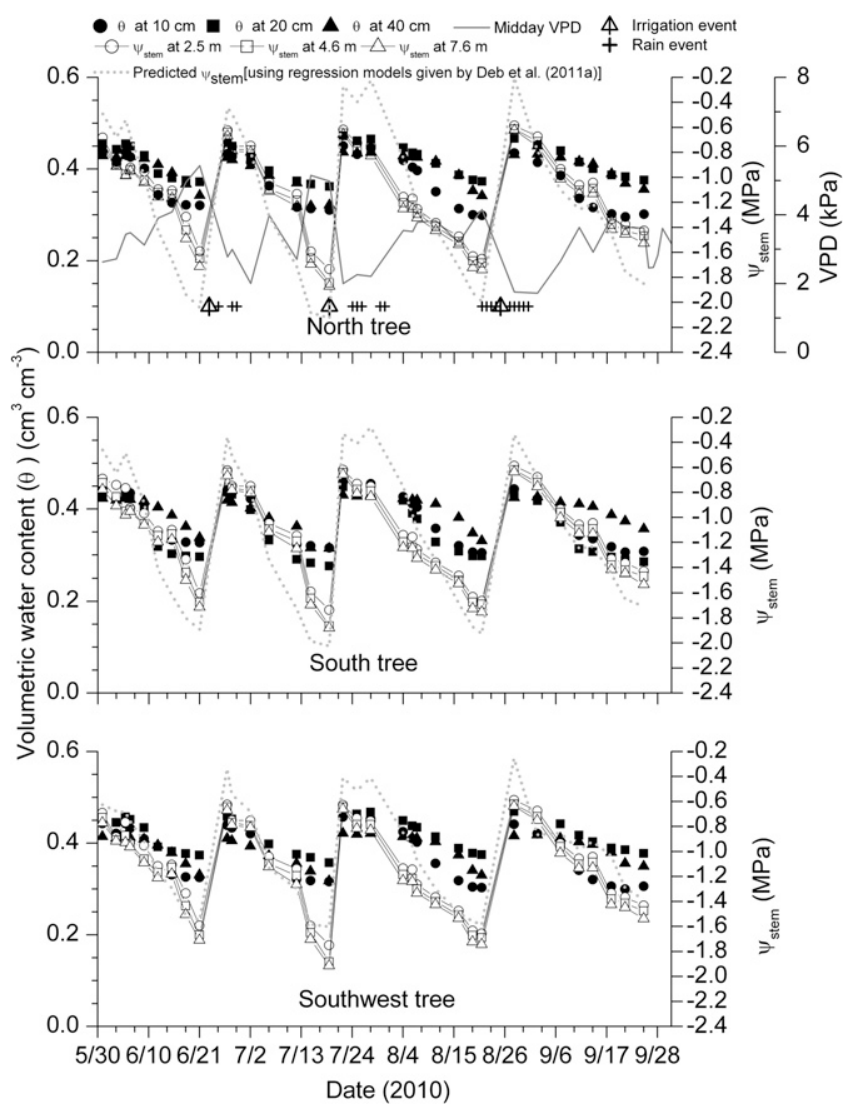

Fig. 4. Midday stem water potential ( $\left.\psi_{\text {stem }}\right)$ at tree heights of $2.5 \mathrm{~m}$ (lower canopy), $4.6 \mathrm{~m}$ (midcanopy), and $7.6 \mathrm{~m}$ (upper canopy) above the soil surface, and volumetric soil water content $(\theta)$ at soil depths of 10 , 20 , and $40 \mathrm{~cm}$ corresponding to $\psi_{\text {stem }}$ measurements taken at identical times during the period from June to Sept. 2010 for the selected north (top), south (middle), and southwest (bottom) pecan trees of Site 2. The predicted $\psi_{\text {stem }}$ using two-parameter [Deb et al. (2011a); relationships between $\psi_{\text {stem }}$ and measured midday $\theta$ within the 0 - to 40 -cm soil depth $\left(\theta_{\text {avg }}\right)$ and midday air temperature $\left(\mathrm{T}_{\mathrm{md}}\right)$ data during 2010] regression models for each tree are also presented. Estimated midday atmospheric vapor pressure deficit (midday VPD) for Site 2 is depicted in the north pecan's (top) plot. Irrigation and rain events during the period of June to Sept. 2010 are shown in the north pecan's (top) plot.
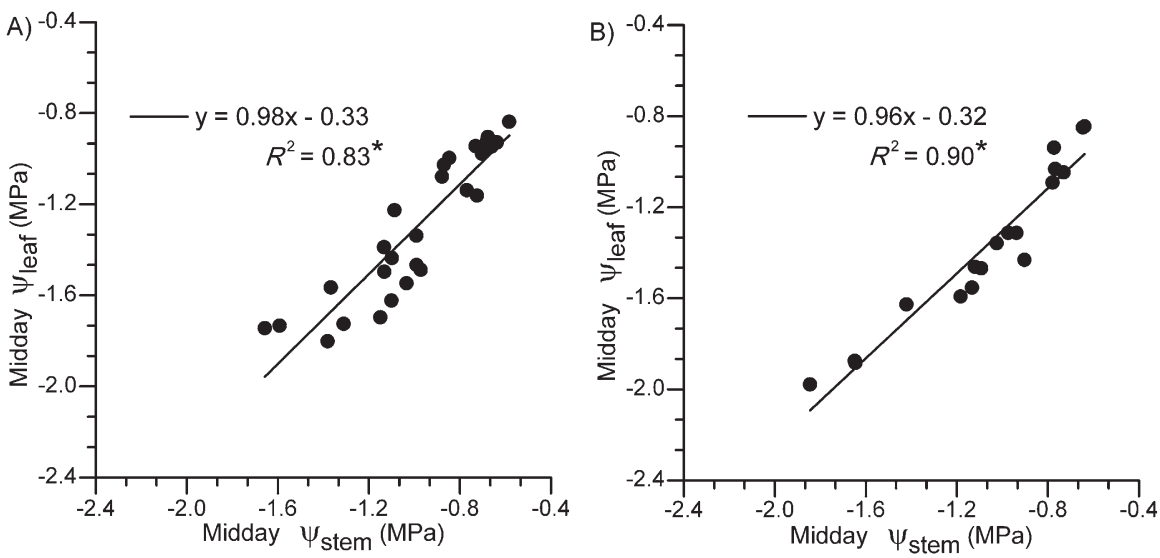

Fig. 5. Relationship between midday leaf water potential $\left(\psi_{\text {leaf }}\right)$ and stem water potential $\left(\psi_{\text {stem }}\right)$ measured at midcanopy (at $4.6 \mathrm{~m}$ tree height above the soil surface) at both Sites 1 and 2 during the period from June to Sept. 2010: (A) for east pecan tree at Site 1 and (B) for north pecan tree at Site 2. ${ }^{*}$ Significant at $P<0.05$.

differences in magnitudes among trees, even under dry soil conditions at both sites. In a previous study, Deb et al. (2011a) found that root-zone soil water depletion within and outside the canopy locations of pecan trees for both sites did not vary spatially. In contrast, for other crops, $\psi_{\text {stem }}$ has been shown to be better related to tree-to-tree differences in water status, particularly in drier soils (Choné et al., 2001; Shackel et al., 1997).

For both sites, because midday $\psi_{\text {stem }}$ and midday $\psi_{\text {leaf }}$ values at lower, mid-, and upper canopy showed similar temporal trends between irrigation events, for ease of interpretation as well as comparison with the predictions of $\psi_{\text {stem }}$ using the regression model (Deb et al., 2011a), temporal variations in midday $\psi_{\text {stem }}$ for selected trees at both sites during the season 2010 are only presented (Figs. 3 and 4). As demonstrated in Figures 3 and 4, similar to diurnal trends (Figs. 1 and 2), temporal patterns of vertical differences in midday $\psi_{\text {stem }}$ values from lower to upper canopy indicated that there was always relatively more plant water stress at the upper canopy compared with the lower canopy at both sites. In contrast, Deb et al. (2011a) reported that midday $\psi_{\text {stem }}$ values at both Sites 1 and 2 during the growing season in 2009 were nearly the same at different heights after irrigation and a decrease in midday $\psi_{\text {stem }}$ with canopy height was observed 10 to $14 \mathrm{~d}$ after the irrigation. Temporal trends of midday $\psi_{\text {stem }}$ and midday $\psi_{\text {leaf }}($ data not shown) over several irrigation cycles in mature pecans at Sites 1 and 2 suggested that the differences in midday $\psi_{\text {stem }}$ or midday $\psi_{\text {leaf }}$ between measurements at different tree heights were not negligible.

Volumetric soil water content and midday stem water potential and leaf water potential. At both sites, the midday $\psi_{\text {stem }}$ followed the cyclic pattern of the $\theta$ between irrigations, and $\psi_{\text {stem }}$ at different canopy heights decreased with decreasing $\theta$ at soil depths of 10, 20, and $40 \mathrm{~cm}$ (Figs. 3 and 4). For example, during the period of 26 June through 11 July 2010 at Site 1 (Fig. 3), after the irrigation on June 26, the $\theta$ at the time of midday $\psi_{\text {stem }}$ measurements, on average, decreased from 0.40 to $0.23 \mathrm{~cm}^{3} \cdot \mathrm{cm}^{-3}$ at $10 \mathrm{~cm}, 0.33$ to $0.27 \mathrm{~cm}^{3} \cdot \mathrm{cm}^{-3}$ at 20 , and 0.33 to $0.25 \mathrm{~cm}^{3} \cdot \mathrm{cm}^{-3}$ at $40 \mathrm{~cm}$ soil depth for the east, south, and north tree. These decreases in $\theta$ corresponded to the decreases in midday $\psi_{\text {stem }}$ during the period of 26 June to 11 July 2010 with midday $\psi_{\text {stem }}$ values measured at lower canopy decreasing from -0.63 to -1.25 $\mathrm{MPa},-0.62$ to $-1.26 \mathrm{MPa}$, and -0.62 to -1.25 $\mathrm{MPa}$ for the east, south, and north trees of Site 1, respectively (Fig. 3). The respective decreases in midday $\psi_{\text {stem }}$ values at midcanopy and upper canopy were from -0.68 to -1.31 $\mathrm{MPa}$ and -0.71 to $-1.36 \mathrm{MPa}$, from -0.67 to $-1.32 \mathrm{MPa}$ and -0.72 to $-1.40 \mathrm{MPa}$, and from -0.66 to $-1.31 \mathrm{MPa}$ and -0.69 to $-1.35 \mathrm{MPa}$ for the east, south, and north trees at Site 1, respectively (Fig. 3).

The volumetric soil water contents $(\theta)$ at soil depths of $5,10,20,40$, and $60 \mathrm{~cm}$ were compared with midday $\psi_{\text {stem }}$ measurements taken at the same times for all trees. Regression analysis was used to evaluate correlations between midday $\psi_{\text {stem }}$ at three canopy heights and $\theta$ at depths of $5,10,20,40$ and $60 \mathrm{~cm}$ for each tree at both sites. Soil water contents $(\theta)$ at depths of $5,10,20$, and $40 \mathrm{~cm}$, and $60 \mathrm{~cm}$ as well as average values of $\theta$ at the soil depth of 0 to $40 \mathrm{~cm}\left(\theta_{\text {avg }}\right)$ were significantly correlated with midday $\psi_{\text {stem }}$ at three canopy heights for each tree at both sites (Deb et al., 2011a). Overall, the values of $R^{2}$ between $\theta$ and midday $\psi_{\text {stem }}$ at different canopies ranged from 0.66 (at $60-\mathrm{cm}$ depth) to 0.78 (at $20 \mathrm{~cm}$ ) $(P<0.05)$ and from $0.72($ at $40 \mathrm{~cm})$ to 0.80 (at $5 \mathrm{~cm})($ at $P<0.05)$ among trees at Sites 1 and 2 , respectively. The relationship between $\theta_{\text {avg }}$ 
and midday $\psi_{\text {stem }}$ at different canopy heights provided the $R^{2}$ ranges of 0.73 to $0.78(P<$ $0.05)$ and 0.80 to $0.82(P<0.05)$ among trees at Sites 1 and 2, respectively (data not presented).

The midday $\psi_{\text {stem }}$ values were lower in trees at the silty clay loam Site 2 than at the sandy loam Site 1, particularly in dry soil conditions (Figs. 3 and 4), in accordance with previously reported data during the 2009 growing season (Deb et al., 2011a). For example, during the period from June to Sept. 2010 , midday $\psi_{\text {stem }}$ values of trees under wet soil conditions measured at midcanopy for both sites converged near $-0.60 \mathrm{MPa}$, whereas under dry soil conditions, midday $\psi_{\text {stem }}$ values at midcanopy were $-1.88 \mathrm{MPa}$ and $-1.66 \mathrm{MPa}$ for trees on silty clay loam (Site 2) and sandy loam soils (Site 1), respectively (Figs. 3 and 4). As shown in Figures 3 and 4, the decrease in midday $\psi_{\text {stem }}$ was because of the increase in midday atmospheric VPD. When the midday $\psi_{\text {stem }}$ and $\psi_{\text {leaf }}$ at three canopy heights were regressed against midday atmospheric VPD, the values of $R^{2}$ ranged from 0.51 to $0.68(P<$ $0.05)$ and 0.67 to $0.85(P<0.05)$ among trees at Sites 1 and 2, respectively (data not presented). The midday $\psi_{\text {stem }}$ and/or $\psi_{\text {leaf }}$ have also been reported to have a linear relationship with the VPD for various crops (Goldhamer and Fereres, 2001; McCutchan and Shackel, 1992; Stern et al., 1998; Stevens et al., 1995; Williams and Baeza, 2007), including mature pecans (Deb et al., 2011a).

Relationship between midday stem water potential and leaf water potential and soil water content and atmospheric vapor pressure deficit parameters. For each tree at both sites during the 2010 season, one-parameter $\left[\psi_{\text {stem }}\right.$ or $\psi_{\text {leaf }}=\mathrm{f}\left(\theta_{\mathrm{avg}}\right.$ or $\left.\left.\mathrm{T}_{\mathrm{md}}\right)\right]$, two-parameter $\left[\psi_{\text {stem }}\right.$ or $\psi_{\text {leaf }}=\mathrm{f}\left(\theta_{\text {avg }}\right.$ and $\mathrm{T}_{\mathrm{md}}$ or $\mathrm{RH}_{\mathrm{md}}$ and $\left.\left.\mathrm{T}_{\mathrm{md}}\right)\right]$, and three-parameter $\left[\psi_{\text {stem }}\right.$ or $\psi_{\text {leaf }}=\mathrm{f}$ $\left(\theta_{\text {avg }}, T_{m d}\right.$, and $\left.\left.\mathrm{RH}_{\mathrm{md}}\right)\right]$ regression models derived using the multiple regression analysis are presented in Tables 1 and 2. Introducing more independent variables to explain the variability of $\psi_{\text {stem }}$ or $\psi_{\text {leaf }}$ improved $R^{2}(P<$ 0.05 ) (Tables 1 and 2). $F$-test showed that in general the two-parameter regression model (between $\psi_{\text {stem }}$ or $\psi_{\text {leaf }}$ and $\theta_{\text {avg }}$ and $\mathrm{T}_{\mathrm{md}}$ ) provided a significantly better fit to the data than one- $\left(\theta_{\mathrm{avg}}\right.$ or $\left.\mathrm{T}_{\mathrm{md}}\right)$, two- $\left(\mathrm{RH}_{\mathrm{md}}\right.$ and $\left.\mathrm{T}_{\mathrm{md}}\right)$, and three-parameter $\left(\theta_{\text {avg }}, \mathrm{T}_{\mathrm{md}}\right.$ and $\left.\mathrm{RH}_{\mathrm{md}}\right)$ models for most of the trees at both sites, suggesting that $\theta_{\text {avg }}$ and $\mathrm{T}_{\mathrm{md}}$ had an important influence on both midday $\psi_{\text {stem }}$ and midday $\psi_{\text {leaf }}$ variation at both sites. Therefore, measurements of $\theta_{\text {avg }}$ and $T_{m d}$ could be made as an adjunct for the simple interpretation of midday $\psi_{\text {stem }}$ or midday $\psi_{\text {leaf }}$ to help refine irrigation scheduling in mature pecan orchards.

In an earlier study on the same pecan orchards, two-parameter regression models similar to the models proposed in this study were developed only for $\psi_{\text {stem }}$ using the measured $\psi_{\text {stem }}$ data for 2009 . Except for north and south pecan trees at Site 2 under dry soil conditions (Fig. 4), the predicted $\psi_{\text {stem }}$ values using these two-parameter models [in Table 6 of Deb et al. (2011a)] for 2010 and 2011 were consistently higher than the measured $\psi_{\text {stem }}$ values (Figs. 3, 4, 6A, and 7A). The most plausible explanation for this underprediction is that measurements in the previous study (Deb et al., 2011a) were made between 1200 and 1400 HR Mountain Standard Time, and $\psi_{\text {stem }}$ was more variable and not minimum. In contrast, using two-parameter regression models $\left[\psi_{\text {stem }}\right.$ or $\psi_{\text {leaf }}=\mathrm{f}$ (midday $\theta_{\text {avg }}$ and $\mathrm{T}_{\mathrm{md}}$ )] developed in this study from 2010 data for both sites (Tables 1 and 2) showed better agreement between the measured and predicted $\psi_{\text {stem }}$ as well as $\psi_{\text {leaf }}$ measured on the both shaded and sunlit sides of pecan trees (Figs. 6 and 7). The values of $R^{2}$ ranged from 0.70 to $0.98(P<0.05)$ among trees at Site 1 , whereas the values of $R^{2}$ were in the range of 0.85 to $0.98(P<0.05)$ among trees at Site 2 . These empirical relationships $\left[\psi_{\text {stem }}\right.$ or $\psi_{\text {leaf }}=\mathrm{f}$ (midday $\theta_{\text {avg }}$ and $\mathrm{T}_{\mathrm{md}}$ )] were evaluated at each of the two pecan orchards, where irrigation scheduling and other management practices, and midday conditions of microclimate variables, particularly air temperature and relative humidity during the period from June to September (Fig. 8), were similar during the 2010 and 2011 seasons. Therefore, the further evaluation of these empirical relationships under different climatic conditions, irrigation, and other pecan management practices may improve their reliability to estimate the water status of mature pecans.

Another aspect to be pointed out from Figures 6 and 7 is that the values of $\psi_{\text {stem }}$ measured at different heights on both shaded and sunlit sides of the tree over several irrigation cycles during the 2011 season were almost the same (Fig. 6A and 7A), whereas the lower values of $\psi_{\text {leaf }}$ of sunlit side leaves in comparison with their shaded counterparts were observed (Fig. 6B and 7B). From this perspective, it could be argued that when the midday parameters $\theta_{\mathrm{avg}}$ and $\mathrm{T}_{\mathrm{md}}$ were used as complementary factors for the interpretation

Table 1. Multiple regression analysis with midday stem water potential ( $\psi_{\text {stem }}$, MPa) at midcanopy (i.e., at $4.6 \mathrm{~m}$ tree height above the soil surface) as the dependent variable and average values of volumetric water content at the shallow soil depth of 0 to $40 \mathrm{~cm}\left(\theta_{\mathrm{avg}}, \mathrm{cm}^{3} \cdot \mathrm{cm}^{-3}\right)$, midday air temperature $\left(\mathrm{T}_{\mathrm{md}},{ }^{\circ} \mathrm{C}\right)$, and midday relative humidity $\left(\mathrm{RH}_{\mathrm{md}}, \%\right)$ as the independent variables.

\begin{tabular}{|c|c|c|c|c|c|}
\hline \multicolumn{3}{|l|}{ Site $1(2010)$} & \multicolumn{3}{|c|}{ Site 2 (2010) } \\
\hline Regression model $^{z}$ & $R^{2 y}$ & $\begin{array}{c}\text { Adjusted } R^{2} \\
(P \text { value; } \mathrm{SEE}) *\end{array}$ & Regression model ${ }^{\mathrm{z}}$ & $R^{2 \mathrm{y}}$ & $\begin{array}{c}\text { Adjusted } R^{2} \\
(P \text { value; SEE })^{*}\end{array}$ \\
\hline East tree: & & & North tree: & & \\
\hline$\psi_{\text {stem }}=0.652-0.054 \times \mathrm{T}_{\mathrm{md}}$ & 0.79 & $0.78(0.00000 ; 0.14)$ & $\psi_{\text {stem }}=1.81-0.094 \times \mathrm{T}_{\mathrm{md}}$ & 0.75 & $0.75(0.00000 ; 0.176)$ \\
\hline$\psi_{\text {stem }}=0.625-0.052 \times \mathrm{T}_{\mathrm{md}}-0.001 \times \mathrm{RH}_{\mathrm{md}}$ & 0.79 & $0.77(0.00000 ; 0.141)$ & $\psi_{\text {stem }}=1.49-0.068 \times \mathrm{T}_{\mathrm{md}}-0.013 \times \mathrm{RH}_{\mathrm{md}}$ & 0.86 & $0.85(0.00000 ; 0.134)$ \\
\hline$\psi_{\mathrm{stem}}=-0.66+2.20 \times \theta_{\mathrm{avg}}-0.0324 \times \mathrm{T}_{\mathrm{md}}$ & 0.84 & $0.83(0.00000 ; 0.12)$ & $\psi_{\text {stem }}=-0.94+3.55 \times \theta_{\mathrm{avg}}-0.05 \times \mathrm{T}_{\mathrm{md}}$ & 0.88 & $0.87(0.00000 ; 0.13)$ \\
\hline $\begin{array}{l}\psi_{\text {stem }}=-0.76+2.29 \times \theta_{\text {avg }}-0.026 \times \\
T_{\text {md }}-0.0036 \times \mathrm{RH}_{\mathrm{md}}\end{array}$ & 0.84 & $0.82(0.00000 ; 0.13)$ & $\begin{array}{l}\psi_{\text {stem }}=-0.297+2.49 \times \theta_{\text {avg }}-0.048 \times \\
T_{\text {md }}-0.0072 \times \mathrm{RH}_{\mathrm{md}}\end{array}$ & 0.90 & $0.89(0.00000 ; 0.11)$ \\
\hline$\psi_{\text {stem }}=-2.33+4.57 \times \theta_{\text {avg }}$ & 0.76 & $0.75(0.00000 ; 0.15)$ & $\psi_{\text {stem }}=-3.34+5.80 \times \theta_{\text {avg }}$ & 0.79 & $0.78(0.00000 ; 0.162)$ \\
\hline$\psi_{\text {stem }}=0.65-0.054 \times \mathrm{T}_{\mathrm{md}}$ & 0.79 & $.78(0.00000 ; 0.1$ & $\psi_{\text {stem }}=1.81-0.094 \times \mathrm{T}_{\mathrm{md}}$ & 0.75 & $0.75(0.00000 ;$ \\
\hline$\psi_{\text {stem }}=0.637-0.053 \times \mathrm{T}_{\mathrm{md}}-0.001 \times$ & 0.79 & $0.77(0.00000 ; 0.141)$ & $\psi_{\text {stem }}=1.487-0.068 \times \mathrm{T}_{\mathrm{md}}-0$ & 0.86 & $0.85(0.00000 ; 0.134)$ \\
\hline$\psi_{\text {stem }}=-0.684+2.26 \times \theta_{\text {avg }}-0.032 \times \mathrm{T}_{\mathrm{md}}$ & 0.84 & $0.83(0.00000 ; 0.12)$ & $\psi_{\text {stem }}=-0.94+3.55 \times \theta_{\mathrm{avg}}-0.005 \times \mathrm{T}_{\mathrm{md}}$ & 0.88 & $0.87(0.00000 ; 0.13)$ \\
\hline $\begin{array}{l}\psi_{\text {stem }}=-0.78+2.35 \times \theta_{\text {avg }}-0.026 \times \\
T_{\text {md }}-0.0035 \times \mathrm{RH}_{\text {md }}\end{array}$ & 0.85 & $0.83(0.00000 ; 0.12)$ & $\begin{array}{l}\psi_{\text {stem }}=-0.297+2.49 \times \theta_{\mathrm{avg}}-0.048 \times \\
\mathrm{T}_{\mathrm{md}}-0.0072 \times \mathrm{RH}_{\mathrm{md}}\end{array}$ & 0.90 & $0.89(0.00000 ; 0.11)$ \\
\hline North tree: & & & Southwest tree: & & \\
\hline $\begin{array}{l}\psi_{\text {stem }}=-0.76+2.29 \times \theta_{\text {avg }}-0.026 \times \\
\quad T_{\text {md }}-0.0036 \times \mathrm{RH}_{\text {md }}\end{array}$ & 0.84 & $0.82(0.00000 ; 0.124)$ & $\begin{array}{l}\psi_{\text {stem }}=-0.62+3.07 \times \theta_{\text {avg }}-0.046 \times \\
T_{\mathrm{md}}+0.007 \times \mathrm{RH}_{\mathrm{md}}\end{array}$ & 0.91 & $0.90(0.00000 ; 0.11)$ \\
\hline
\end{tabular}

${ }^{\mathrm{z}}$ For each tree, one-parameter regression model (regression between $\psi_{\text {stem }}$ and $\theta_{\text {avg }}$ and between $\psi_{\text {stem }}$ and $\mathrm{T}_{\text {md }}$ ), two-parameter regression model (multiple regression between $\psi_{\text {stem }}$ and $\theta_{\text {avg }}$ and $\mathrm{T}_{\mathrm{md}}$; between $\psi_{\text {stem }}$ and $\mathrm{RH}_{\mathrm{md}}$ and $\mathrm{T}_{\mathrm{md}}$ ), and three-parameter regression model (multiple regression between $\psi_{\text {stem }}$ and $\theta_{\text {avg }}$, $\mathrm{T}_{\mathrm{md}}$, and $\mathrm{RH}_{\mathrm{md}}$ ).

${ }^{y} R^{2}=$ the coefficient of determination.

$* P$ value from analysis of variance section of the regression (significant at $P<0.05$ ).

$\mathrm{SEE}=\mathrm{SE}$ of estimate. 
Table 2. Multiple regression analysis with midday leaf water potential ( $\left.\psi_{\text {leaf }}, \mathrm{MPa}\right)$ at midcanopy (i.e., at $4.6 \mathrm{~m}$ tree height above the soil surface) as the dependent variable and average values of volumetric water content at the shallow soil depth of 0 to $40 \mathrm{~cm}\left(\theta_{\text {avg }}, \mathrm{cm}^{3} \cdot \mathrm{cm}^{-3}\right)$, midday air temperature $\left(\mathrm{T}_{\mathrm{md}},{ }^{\circ} \mathrm{C}\right)$, and midday relative humidity $\left(\mathrm{RH}_{\mathrm{md}}, \%\right)$ as the independent variables.

\begin{tabular}{|c|c|c|c|c|c|}
\hline \multicolumn{3}{|l|}{ Site $1(2010)$} & \multicolumn{3}{|l|}{ Site $2(2010)$} \\
\hline Regression model $^{\mathrm{z}}$ & $R^{2 \mathrm{y}}$ & $\begin{array}{c}\text { Adjusted } R^{2} \\
(P \text { value; } \mathrm{SEE})^{*}\end{array}$ & Regression model ${ }^{\mathrm{z}}$ & $R^{2 y}$ & $\begin{array}{c}\text { Adjusted } R^{2} \\
(P \text { value; } \mathrm{SEE})^{*}\end{array}$ \\
\hline East tree: & & & North tree: & & \\
\hline$\psi_{\text {leaf }}=0.46-0.058 \times \mathrm{T}_{\mathrm{md}}$ & 0.78 & $0.77(0.00000 ; 0.15)$ & $\psi_{\text {leaf }}=1.60-0.096 \times \mathrm{T}_{\mathrm{md}}$ & 0.772 & $0.77(0.00000 ; 0.172)$ \\
\hline$\psi_{\text {leaf }}=0.578-0.076 \times \mathrm{T}_{\mathrm{md}}-0.011 \times \mathrm{RH}_{\mathrm{md}}$ & 0.80 & $0.79(0.00000 ; 0.145)$ & $\psi_{\text {leaf }}=1.37-0.08 \times \mathrm{T}_{\mathrm{md}}-0.009 \times \mathrm{RH}_{\mathrm{md}}$ & 0.83 & $0.81(0.00000 ; 0.151)$ \\
\hline$\psi_{\text {leaf }}=-0.97+2.37 \times \theta_{\text {avg }}-0.034 \times \mathrm{T}_{\mathrm{md}}$ & 0.83 & $.82(0.00000 ; 0.135)$ & $\psi_{\text {leaf }}=-0.194+2.321 \times \theta_{\text {avg }}-0.07 \times \mathrm{T}_{\text {md }}$ & 0.83 & $0.81(0.00000 ; 0.152)$ \\
\hline $\begin{array}{l}\psi_{\text {leaf }}=-0.73+2.16 \times \theta_{\text {avg }}-0.051 \times \\
\mathrm{T}_{\mathrm{md}}+0.009 \times \mathrm{RH}_{\mathrm{md}} \\
\text { South tree: }\end{array}$ & 0.84 & $0.83(0.00000 ; 0.13)$ & $\begin{array}{l}\psi_{\text {leaf }}=0.354+1.411 \times \theta_{\text {avg }}-0.066 \times \\
T_{\text {md }}-0.006 \times \mathrm{RH}_{\mathrm{md}} \\
\text { South tree: }\end{array}$ & 0.84 & $0.83(0.00000 ; 0.15)$ \\
\hline$\psi_{\text {leaf }}=-2.74+4.90 \times \theta_{\text {avg }}$ & 0.75 & $.74(0.00000 ; 0.163)$ & $\psi_{\text {leaf }}=-3.46+5.38 \times \theta_{\text {avg }}$ & 0.67 & $0.65(0.00000 ; 0.21)$ \\
\hline$\psi_{\text {leaf }}=0.45-0.058 \times \mathrm{T}_{\mathrm{md}}$ & 0.77 & $0.76(0.00000 ; 0.15$ & $\psi_{\text {leaf }}=1.60-0.096 \times \mathrm{T}_{\mathrm{md}}$ & 0.772 & $0.77(0.00016 ; 0.172)$ \\
\hline$\psi_{\text {leaf }}=0.602-0.077 \times \mathrm{T}_{\mathrm{md}}-0.011 \times \mathrm{RH}_{\mathrm{md}}$ & 0.80 & $0.78(0.00000 ; 0.149)$ & $\psi_{\text {leaf }}=1.37-0.08 \times \mathrm{T}_{\mathrm{md}}-0.009 \times \mathrm{RH}_{\mathrm{md}}$ & 0.83 & $0.81(0.00000 ; 0.151)$ \\
\hline$\psi_{\text {leaf }}=-0.99+2.44 \times \theta_{\text {avg }}-0.034 \times \mathrm{T}_{\mathrm{md}}$ & 0.83 & $0.81(0.00000 ; 0.14)$ & $\psi_{\text {leaf }}=-0.194+2.321 \times \theta_{\text {avg }}-0.066 \times \mathrm{T}_{\mathrm{md}}$ & 0.83 & $0.81(0.00000 ; 0.153)$ \\
\hline $\begin{array}{l}\psi_{\text {leaf }}=-0.74+2.23 \times \theta_{\text {avg }}-0.051 \times \\
\mathrm{T}_{\mathrm{md}}+0.009 \times \mathrm{RH}_{\mathrm{md}}\end{array}$ & 0.84 & $0.82(0.00000 ; 0.134)$ & $\begin{array}{l}\psi_{\text {leaf }}=0.354+1.411 \times \theta_{\text {avg }}-0.066 \times \\
T_{\text {md }}-0.006 \times \mathrm{RH}_{\mathrm{md}}\end{array}$ & 0.84 & $0.83(0.00000 ; 0.15)$ \\
\hline North tre & & & & & \\
\hline $\begin{array}{l}\psi_{\text {leaf }}=-0.72+2.16 \times \theta_{\text {avg }}-0.051 \times \\
\mathrm{T}_{\mathrm{md}}+0.009 \times \mathrm{RH}_{\mathrm{md}}\end{array}$ & 0.84 & $0.83(0.00000 ; 0.13)$ & $\begin{array}{l}\psi_{\text {leaf }}=0.194+1.722 \times \theta_{\text {avg }}-0.066 \times \\
T_{\mathrm{md}}-0.006 \times \mathrm{RH}_{\mathrm{md}}\end{array}$ & 0.84 & $0.83(0.00000 ; 0.15)$ \\
\hline
\end{tabular}

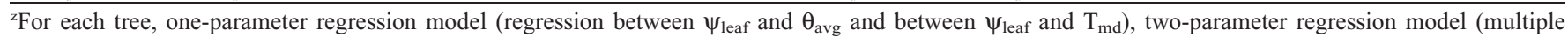
regression between $\psi_{\text {leaf }}$ and $\theta_{\text {avg }}$ and $\mathrm{T}_{\mathrm{md}}$; between $\psi_{\text {leaf }}$ and $\mathrm{RH}_{\mathrm{md}}$ and $\mathrm{T}_{\mathrm{md}}$ ), and three-parameter regression model (multiple regression between $\psi_{\text {leaf }}$ and $\theta_{\text {avg }}$, $\mathrm{T}_{\mathrm{md}}$, and $\left.\mathrm{RH}_{\mathrm{md}}\right)$.

${ }^{\mathrm{y}} R^{2}=$ the coefficient of determination.

$* P$ value from analysis of variance section of the regression (significant at $P<0.05$ ).

$\mathrm{SEE}=\mathrm{SE}$ of estimate.
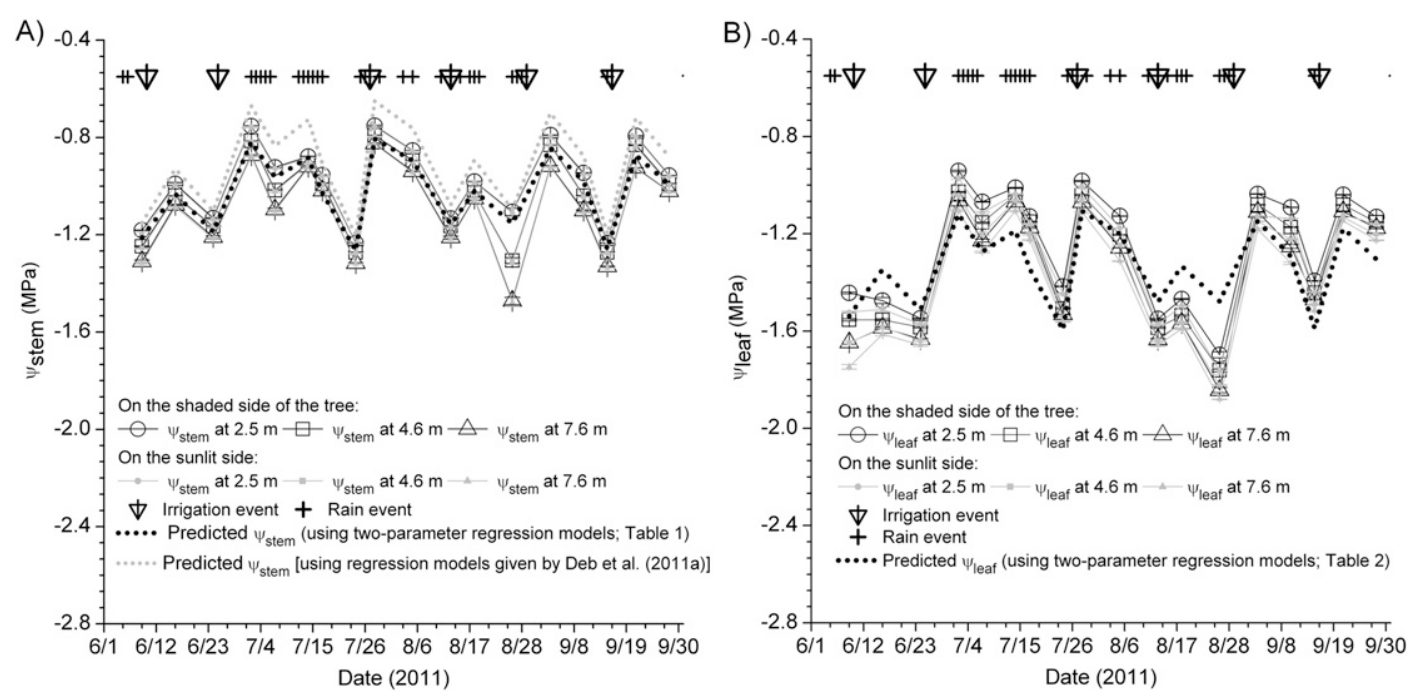

Fig. 6. Midday stem water potential $\left(\psi_{\text {stem }}\right)$ and midday leaf water potential $\left(\psi_{\text {stem }}\right)$ measured on the both shaded and sunlit sides of the tree at heights of $2.5 \mathrm{~m}$ (lower canopy), $4.6 \mathrm{~m}$ (midcanopy), and $7.6 \mathrm{~m}$ (upper canopy) above the soil surface, and the predicted $\psi_{\text {stem }}$ using the two-parameter regression models at Site 1 during the period from June to Sept. 2011: (A) measured midday $\psi_{\text {stem }}$ vs. predicted $\psi_{\text {stem }}$ using two-parameter [multiple regression between $\psi_{\text {stem }}$, and $\theta_{\text {avg }}$ and $\mathrm{T}_{\mathrm{md}}$ (Table 1); and Deb et al. (2011a)] regression models, and (B) measured midday $\psi_{\text {leaf }}$ vs. predicted $\psi_{\text {leaf }}$ using the two-parameter (multiple regression between $\psi_{\text {leaf }}$ and $\theta_{\text {avg }}$ and $\mathrm{T}_{\mathrm{md}}$; Table 2 ) regression models. The measured $\psi_{\text {stem }}$ and $\psi_{\text {leaf }}$ values at each tree height represent the averages of six measurements on each of shaded and sunlit sides of the selected east, south, and north pecan trees at Site 1.

of either midday $\psi_{\text {stem }}$ or midday $\psi_{\text {leaf }}$ at both sandy loam and silty clay loam sites, it might be more favorable to choose midday $\psi_{\text {stem }}$ because it provided a relatively stable indicator of mature pecan water status on both shaded and sunlit sides of the pecan canopy.

\section{Conclusions}

Diurnal patterns of $\psi_{\text {stem }}$ and $\psi_{\text {leaf }}$ of both the dry and wet soil conditions measured at three canopy heights for flood-irrigated mature pecan orchards with sandy loam (Site 1) and silty clay loam (Site 2) soil textures suggested that midday measurements of $\psi_{\text {stem }}$ and $\psi_{\text {leaf }}$ should be made in midafternoon (between 1400 and 1500 HR Mountain Standard Time) to determine water stress in mature pecans that responded to potential climatic conditions. Diurnal measurements of $\psi_{\text {stem }}$ and $\psi_{\text {leaf }}$ at three canopy heights were significantly correlated under both the dry and wet soil conditions. However, although soil water contents at Site 2 remained higher as compared with Site $1, \psi_{\text {stem }}$ and $\psi_{\text {leaf }}$ values, particularly under dry soil conditions at Site 2 in contrast to Site 1, were consistently more negative, indicating that soil texture has an important effect on pecan water stress, and the flow of water from soil to roots might be influenced in part by more clayey soil at this Site 2 . Midday $\psi_{\text {stem }}$ and midday $\psi_{\text {leaf }}$ at three canopy heights over several irrigation cycles 

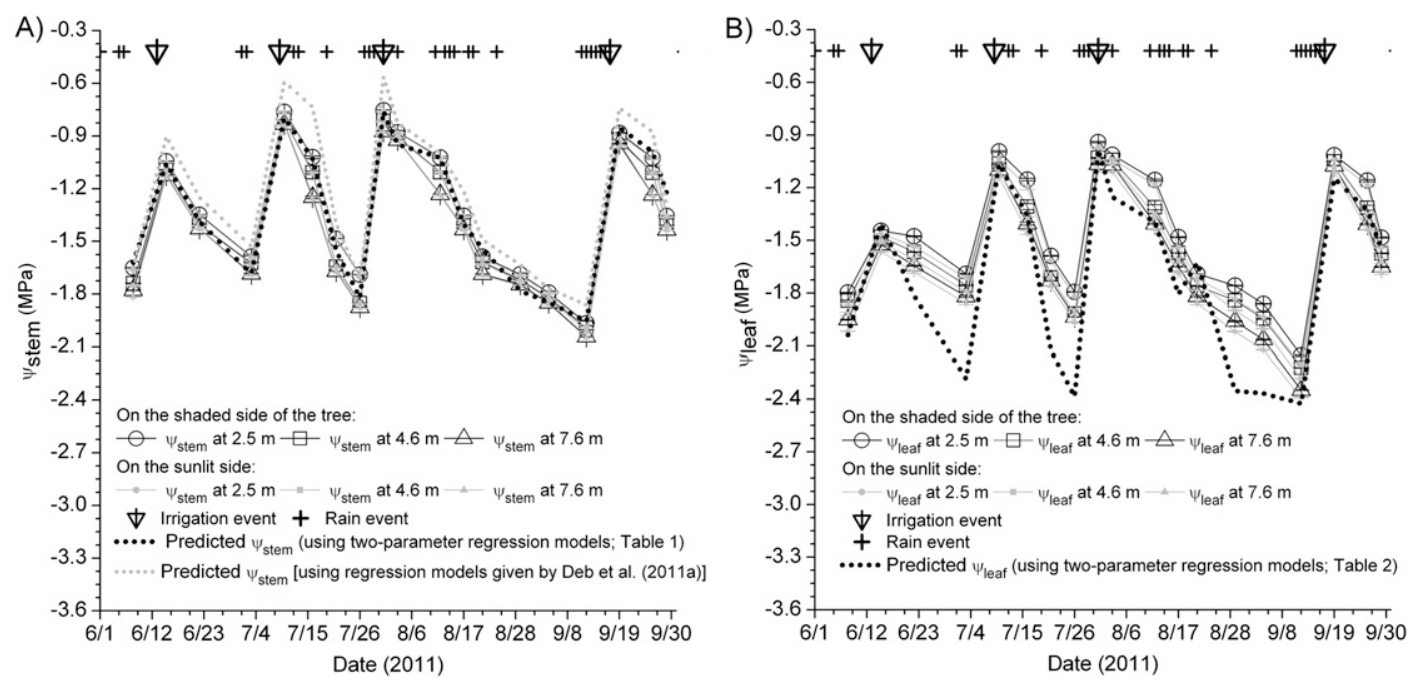

Fig. 7. Midday stem water potential $\left(\psi_{\text {stem }}\right)$ and midday leaf water potential $\left(\psi_{\text {stem }}\right)$ measured on the both shaded and sunlit sides of the tree at heights of $2.5 \mathrm{~m}$ (lower canopy), $4.6 \mathrm{~m}$ (midcanopy), and $7.6 \mathrm{~m}$ (upper canopy) above the soil surface, and the predicted $\psi_{\text {stem }}$ using the two-parameter regression models at Site 2 during the period from June to Sept. 2011: (A) measured midday $\psi_{\text {stem }}$ vs. predicted $\psi_{\text {stem }}$ using three-parameter [multiple regression between $\psi_{\text {stem }}$, and $\theta_{\text {avg }}$ and $\mathrm{T}_{\mathrm{md}}$ (Table 1); and Deb et al. (2011a)] regression models, and (B) measured midday $\psi_{\text {leaf }}$ vs. predicted $\psi_{\text {leaf }}$ using two-parameter (multiple regression between $\psi_{\text {leaf }}$ and $\theta_{\text {avg }}$ and $\mathrm{T}_{\mathrm{md}}$; Table 2) regression models. The measured $\psi_{\text {stem }}$ and $\psi_{\text {leaf }}$ values at each tree height represent the averages of six measurements on each of shaded and sunlit sides of the selected north, south, and southwest pecan trees at Site 2.

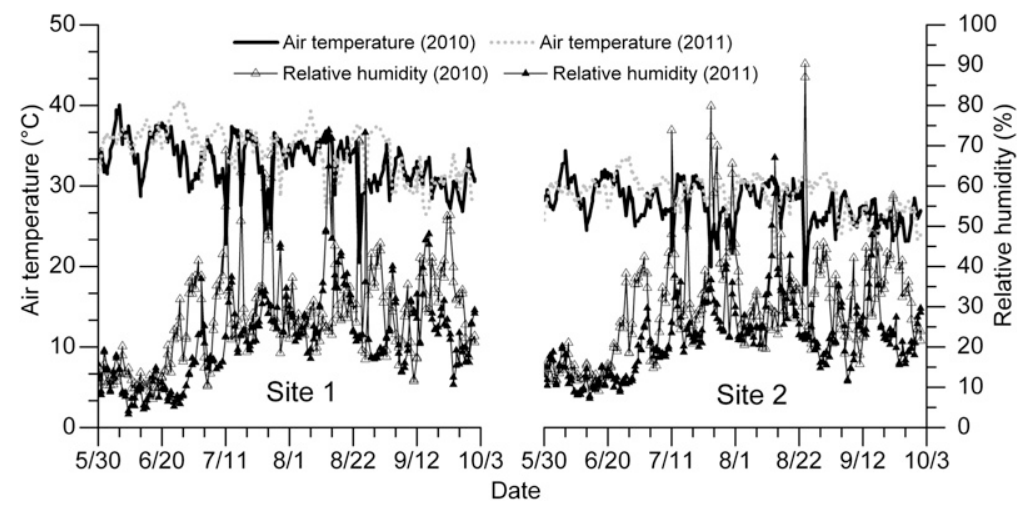

Fig. 8. Midday air temperature $\left(\mathrm{T}_{\mathrm{md}}\right)$ and relative humidity $\left(\mathrm{RH}_{\mathrm{md}}\right)$ (1400 to 1500 HR Mountain Standard Time) at both Sites 1 and 2 during the 2010 and 2011 seasons.

during the 2010 season were correlated with one another, midday soil water content at different soil depths and within the shallow depths $\left(\theta_{\text {avg }}\right)$, and midday atmospheric VPD at each tree and site. To evaluate the effect that soil water status and climatic parameters had on both midday $\psi_{\text {stem }}$ and $\psi_{\text {leaf }}$ during the 2010 season, multiple regression analysis (between midday $\psi_{\text {stem }}$ or $\psi_{\text {leaf }}$ and midday $\theta_{\text {avg }}, T_{\text {md, }}$, and $\mathrm{RH}_{\mathrm{md}}$ ) revealed that two-parameter multiple regression models (relationships between midday $\psi_{\text {stem }}$ or $\psi_{\text {leaf }}$ and midday $\theta_{\text {avg }}$ and $\left.\mathrm{T}_{\mathrm{md}}\right)$ were the most significant for the interpretation of midday $\psi_{\text {stem }}$ or $\psi_{\text {leaf }}$ at both sites. The predictions of average $\psi_{\text {stem }}$ and $\psi_{\text {leaf }}$ using these two-parameter models were correlated with midday $\psi_{\text {stem }}$ and midday $\psi_{\text {leaf }}$ measured on the both shaded and sunlit sides of trees at three canopy heights during 2011. Midday measurements of $\psi_{\text {stem }}$ and $\psi_{\text {leaf }}$ on both shaded and sunlit sides of the pecan canopy during the 2011 season suggested that midday $\psi_{\text {stem }}$ in contrast to midday $\psi_{\text {leaf }}$ provided a relatively stable indicator of mature pecan water status.
Measurements of $\psi_{\text {stem }}$ or $\psi_{\text {stem }}$ using the pressure chamber method are expensive, timeconsuming, and destructive sampling of stems is required. It is easier to monitor soil water content and air temperature continuously, and these two-parameter models (relationships between midday $\psi_{\text {stem }}$ or $\psi_{\text {leaf }}$ and midday $\theta_{\text {avg }}$ and $\mathrm{T}_{\mathrm{md}}$ ) could be useful for the simple interpretation of midday $\psi_{\text {stem }}$ and $\psi_{\text {leaf }}$ to help refine irrigation scheduling of pecans. However, the further evaluation of relationships between midday $\psi_{\text {stem }}$ or $\psi_{\text {leaf }}$ and midday $\theta_{\text {avg }}, \mathrm{T}_{\mathrm{md}}$, and $\mathrm{RH}_{\mathrm{md}}$ under different irrigation and other pecan management practices, soils, and climatic conditions is recommended to improve the reliability of these empirical relationships to estimate the water status of mature pecans.

\section{Literature Cited}

Begg, J.E. and N.C. Turner. 1970. Water potential gradients in field tobacco. Plant Physiol. 46:343346.

Choné, X., C. van Leeuwen, D. Dubourdieu, and J.P. Gaudillère. 2001. Stem water potential is a sensitive indicator of grapevine water status. Ann. Bot. (Lond.) 87:477-483.

Deb, S.K., M.K. Shukla, J.G. Mexal, and P. Sharma. 2011a. Soil water depletion in irrigated mature pecans under contrasting soil textures for arid southern New Mexico. Irrig. Sci. DOI: 10.1007/ s00271-011-0293-1.

Deb, S.K., M.K. Shukla, and J.G. Mexal. 2011b. Numerical modeling of water fluxes in the root zone of a mature pecan orchard. Soil Sci. Soc. Amer. J. 75:1667-1680.

Dixon, M.A. and M.T. Tyree. 1984. A new stem hygrometer, corrected for temperature-gradients and calibrated against the pressure bomb. Plant Cell Environ. 7:693-697.

Fulton, A., R. Buchner, B. Olsen, L. Schwank1, C. Gilles, N. Bertagna, J. Walton, and K. Shackel. 2001. Rapid equilibration of leaf and stem water potential under field conditions in almonds, walnuts, and prunes. HortTechnolgy 11:609-615.

Garnier, E. and A. Berger. 1985. Testing water potential in peach tree as an indicator of water stress. J. Hort. Sci. 60:47-56.

Goldhamer, D.A. and E. Fereres. 2001. Simplified tree water status measurements can aid almond irrigation. Calif. Agr. 55:32-37.

Grimes, D.W. and L.E. Williams. 1990. Irrigation effects on plant water relations and productivity of 'Thompson Seedless' grapevines. Crop Sci. 30:255-260.

Hellkvist, J., G.P. Richards, and P.G. Jamis. 1974. Vertical gradients of water potential and issue water relations in Sitka spruce trees measured with the pressure chamber. J. Appl. Ecol. 11:637-668.

Intrigliolo, D.S. and J.R. Castel. 2006a. Vine and soilbased measures of water status in a Tempranillo vineyard. Vitis 45:157-163.

Intrigliolo, D.S. and J.R. Castel. 2006b. Performance of various water stress indicators for prediction of fruit size response to deficit irrigation in plum. Agr. Water Mgt. 83:173-180.

Jones, H.G. 1990. Physiological aspects of the control of water status in horticultural crops. HortScience 25:19-26.

Jones, H.G. 2004. Irrigation scheduling: Advantages and pitfalls of plant-based methods. J Experim. Bot. 55:2427-2436. 
Loveys, B.R., H.G. Jones, J.C. Theobald, and M.G. McCarthy. 2008. An assessment of plant-based measures of grapevine performance as irrigationscheduling tools. Acta Hort. 792:391-403.

Marsal, J., M. Mata, J. del Campo, A. Arbones, X. Vallverdú, J. Girona, and N. Olivo. 2008. Evaluation of partial root-zone drying for potential field use as a deficit irrigation technique in commercial vineyards according to two different pipeline layouts. Irrig. Sci. 26:347-356.

McCutchan, H. and K.A. Shackel. 1992. Stemwater potential as a sensitive indicator of water stress in prune trees (Prunus domestica L. cv. French). J. Amer. Soc. Hort. Sci. 117:607-611.

Meyer, W.S. and G.C. Green. 1980. Water use by wheat and plant indicators of available soil water. Agron. J. 72:253-257.

Murray, F.W. 1967. On the computation of saturation vapor pressure. J. Appl. Meteorol. 6:203204.

Naor, A. 1998. Relations between leaf and stem water potentials and stomata conductance in three field-grown woody species. J. Hort. Sci. Biotechnol. 73:431-436.

Naor, A., Y. Gal, and M. Peres. 2006. Inherent variability of a few water stress indicators in apple, nectarine and pear orchards, and the validity of a commercial leaf-selection procedure for water potential measurements. Irrig. Sci. 24:129-135.

Naor, A., H. Hupert, Y. Greenblat, M. Peres, and I. Klein. 2001. The response of nectarine fruit size and midday stem water potential to irrigation level in stage III and crop load. J. Amer. Soc. Hort. Sci. 126:140-143.

Naor, A., I. Klein, and I. Doron. 1995. Stem water potential and apple size. J. Amer. Soc. Hort. Sci. 120:577-582.

Olivo, N., J. Girona, and J. Marsal. 2009. Seasonal sensitivity of stem water potential to vapour pressure deficit in grapevine. Irrig. Sci. 27:175182.

Remorini, D. and R. Massai. 2003. Comparison of water status indicators for young peach trees. Irrig. Sci. 22:39-46.

Scholander, P.F., H.J. Hammel, A. Bradstreet, and E.A. Hemmingsen. 1965. Sap pressure in vascular plants. Science 148:339-346.

Selles, G. and A. Berger. 1990. Physiological indicators of plant water status as criteria for irrigation scheduling. Acta Hort. 278:87-100.

Shackel, K.A., H. Ahmadi, W. Biasi, R. Buchner, D. Godhamer, S. Gurusinghe, J. Hasey, D. Kester, B. Krueger, G. Lampinen, W. McGourty, W. Micke, E. Mitcham, B. Olson, K. Pelletrau, H. Philips, D. Ramos, L. Schwankl, S. Sibebett, S. Southwick, M. Stevenson, M. Thorpe, S. Weinbaum, and J. Yeager. 1997. Plant water status as an index of irrigation need in deciduous fruit trees. HortTechnology 7:23-29.

Stern, R.A., M. Meron, A. Naor, R. Wallach, B. Bravdo, and S. Gazit. 1998. Effect of fall irrigation level in 'Mauritius' and 'Floridian' lychee on soil and plant water status, flowering intensity, and yield. J. Amer. Soc. Hort. Sci. 123:150-155.
Stevens, R.M., G. Harvey, and D. Aspinall. 1995. Grapevine growth of shoots and fruit linearly correlated with water stress indices based on root-weighted soil matric potential. Aust. J. Grape Wine Res. 1:58-66.

Turner, N.C. and M.J. Long. 1980. Errors arising from rapid water loss in the measurement of leaf water potential by the pressure chamber technique. Aust. J. Plant Physiol. 7:527-537.

van Zyl, J.L. 1987. Diurnal variation in grapevine water stress as a function of changing soil water status and meteorological conditions. S. Afr. J. Enol. Viticult. 8:45-52.

Williams, L.E. and F.J. Araujo. 2002. Correlations among predawn leaf, midday leaf, and midday stem water potential and their correlations with other measures of soil and plant water status in Vitis vinifera. J. Amer. Soc. Hort. Sci. 127:448454.

Williams, L.E. and T.J. Trout. 2005. Relationships among vine- and soil-based measures of water status in a Thompson Seedless vineyard in response to high-frequency drip irrigation. Amer. J. Enol. Viticult. 56:357-366.

Williams, L.E., N.K. Dokoozlian, and R.L. Wample. 1994. Grape, p. 83-133. In: Shaffer, B. and P.C. Anderson (eds.). Handbook of environmental physiology of fruit crops. Vol. 1. Temperate crops. CRC Press, Orlando, FL.

Williams, L.E. and P. Baeza. 2007. Relationships among ambient temperature and vapor pressure deficit and leaf and stem water potentials of fully irrigated, field-grown grapevines. Amer. J. Enol. Viticult. 58:173-181. 